\title{
Wealth Stratification in the Early School Career in Germany
}

Jascha Dräger and Nora Müller

GESIS - Leibniz Institute for the Social Sciences

\begin{abstract}
Recent research has established parental wealth as an important determinant of children's educational achievement. However, parental wealth is often ignored in research on social inequality in education, or its influence is only considered at later stages of children's educational careers. Our paper contributes to this research by examining the relationship between parental wealth and (1) children's math competences at the beginning of primary school; (2) the development of children's competences throughout primary school; and (3) children's transition from primary to secondary school. We are looking at Germany, where the early ability tracking may make an early investment in education particularly important. Analyzing data from the German National Educational Panel Study, we find that parental wealth has a distinct association with children's educational outcomes that adds to social disparities by other measures of parents' socioeconomic status (SES). Our results indicate that children in wealthy households have higher competences already in the first grade. This advantage remains stable throughout primary school and translates into a higher probability to attend the highest secondary school track. Moreover, children in these wealthy households are more likely to attend the highest secondary school track, net of differences in competences and performance. Our results imply that ignoring wealth as a component of parental SES leads to an underestimation of the level of social inequality in education in Germany.
\end{abstract}

\section{Keywords}

Educational Decisions; Mathematical Competence; Primary and Secondary Effects; Stratification; Wealth 


\section{Introduction}

Children's parental social background crucially shapes their educational achievement, thus reproducing social inequality between generations (Blau \& Duncan, 1967). Studies have found that children of parents with high socioeconomic status (SES) have on average higher competences and show better performance in school than children with low SES (Bradley \& Corwyn, 2002). As a consequence of their better performance, they are more likely to make more ambitious educational decisions (i.e., primary effect of social origin) and they are more likely to receive higher educational degrees. Yet, children of parents with high SES make more ambitious educational decisions even when they have the same competences and school performance as children of parents with low SES (i.e., secondary effect of social origin) (Boudon, 1974; Jackson, 2013).

To approximate parental SES, researchers usually use measures of parental education, income or occupational class. However, recent research on the United States, Sweden and Norway suggests that parental wealth should be added to the existing measures comprising parental SES, to better capture social inequalities in education (Elliott \& Sherraden, 2013; Hällsten \& Pfeffer, 2017; Pfeffer, 2018; Wiborg, 2017). Ignoring wealth as a specific dimension of SES may result in an underestimation of social stratification in education.

Wealth possesses specific features that are not captured by traditional measures of SES, but that contribute to social stratification in unique ways. Wealth can stem either from self-accumulation over one's own life-course or from transfers (e.g., inter-vivo transfers or bequests). Unlike earned income, education or occupational status, the accumulation of which generally requires time, effort, and ability, transferred wealth offers access to capital and goods independently of the individual's decisions or their abilities. Because wealth is less volatile than income, it is a more accurate indicator of an individual's or household's long-term consumption potential and capacity to maintain a particular standard of living (Spilerman, 2000). Yet, wealth does not have to be consumed in order to affect behavior. The mere expectation of incoming wealth and the potential use of wealth can impact individual behavior (Brown, Coile, \& Weisbenner, 2010).

The association between children's competences and their educational performance with parental wealth follows the same pattern as what previous research has found for other measures of parental SES. Children of wealthy parents have higher competences and show better performance 
in school as compared to children of less wealthy parents. In the United States, children in wealthy households were found to have higher test scores in math than children of less wealthy households (Friedline, Masa, \& Chowa, 2015; Orr, 2003; Williams Shanks, 2007; Yeung \& Conley, 2008). The findings for the association between parental wealth and reading test scores are, however, inconsistent (Elliott, Destin, \& Friedline, 2011). For Sweden, Hällsten \& Pfeffer (2017) found a substantial positive association between parental wealth and children's grade point average (GPA) in the ninth grade. Wiborg (2017) observed the same for Norway. Cesarini, Lindqvist, Östling, \& Wallace (2016), however, found no association between lottery wins and children's competences or GPA in Sweden. This last finding suggests that wealth may have different impacts on children's educational outcomes, depending on whether children grow up with the knowledge of the existence of parental wealth or not (Hällsten \& Pfeffer, 2017, p. 331).

Additionally, parental wealth has been found to be associated with more ambitious educational decisions and higher educational attainment. Research on the United States showed that children of wealthy parents were more likely to attend college as compared to children with less wealthy parents (Conley, 2001; Jez, 2014; Pfeffer, 2018; Zhan, 2006). In Sweden, children of wealthy parents were also more likely to attend and graduate from academic secondary school tracks and to choose tertiary fields of study, which are associated with higher earnings (Hällsten \& Pfeffer, 2017; Hällsten \& Thaning, 2018). In the only study on Germany, Pfeffer (2011) analyzed the effect of parental wealth on children's educational attainment measured as the number of years of schooling attained. He found a positive and statistically significant association between parental wealth and children's educational attainment. While parental education shows the highest partial correlation with children's educational attainment, the correlation with parental wealth was of similar magnitude as the correlations with income and occupational class.

The relationship between parental wealth and children's educational outcomes can be expected to become even more relevant in the future, given that wealth inequality has grown during the last decades in most Western countries (Piketty \& Zucman, 2014). Yet, important research gaps remain. First, there is a lack of research in countries other than the United States, Norway, and Sweden. The results for these countries are probably not generalizable to most other countries because of different educational and welfare state systems. 
Second, there are few studies on the relationship between parental wealth and children's early educational outcomes. But past research has shown that social stratification of competences emerges already for young children (Feinstein, 2003; Linberg, Schneider, Waldfogel, \& Wang, 2019) and that early investments in competences are more effective than later ones (Cunha \& Heckman, 2008). With regards to parental wealth, research has not yet shown when social disparities emerge, nor how these develop throughout the early years of schooling.

Third, most existing studies on wealth stratification in education looked either at performance in school or test scores or at educational decisions. Therefore, they cannot differentiate between primary and secondary effects of parental wealth or they only hinted at this differentiation (Hällsten \& Pfeffer, 2017; Huang, Guo, Kim, \& Sherraden, 2010). Policy implications, however, would differ depending on whether primary or secondary effects are more relevant for children's educational outcomes.

In this paper, we aim to make two contributions to reduce these research gaps: First, we assess the association between parental wealth and early educational outcomes in an institutional context with an early and important educational decision, namely the transition to different secondary school tracks after elementary school in Germany. This early tracking may make an early investment in education particularly important. Within this context, we examine the relationship between parental wealth and (1) children's competences ${ }^{1}$ at the beginning of primary school; (2) the development of competences throughout primary school; and (3) children's transition to secondary school.

Second, we integrate wealth stratification in the transition to secondary school tracks in the framework of primary and secondary effects, both theoretically and empirically.

\footnotetext{
${ }^{1}$ In line with the OECD (2013), we understand competences to "refer to the ability or capacity of an agent to act appropriately in a given situation" (p. 19), especially to someone's proficiency in performing certain tasks. In this sense, competences can be used interchangeably with skills.
} 


\section{The German Context}

\subsection{Educational System}

Similar to Scandinavian countries and in contrast to the United States, most children in Germany attend the public education system, which is free from tuition fees. Financial resources of schools are more equally distributed in Germany as compared to the United States as schools are funded centrally by the federal states and not by taxes levied in the municipality. German citizens enjoy a more generous social security system than their American counterparts. Just like in the Scandinavian countries, in Germany private institutionalized education is of limited importance. Based on these characteristics, we expect a weak association between parental wealth and children's educational outcomes in Germany.

However, the early tracking in the German educational system may magnify the effects of parental wealth on educational outcomes for young children. In the majority of German Federal States, after only four years of schooling, children are tracked based on their academic abilities into a tripartite system of secondary schooling. The least advanced track, Hauptschule, is nine grades long, and it prepares students for manual jobs. Realschule is the intermediate track. Ten grades long, it prepares students for skilled non-manual jobs. The most advanced track, Gymnasium, is twelve or thirteen grades long, and it is the only track that offers students immediate access to tertiary education. Schools usually offer one of the three tracks. Additionally, there are comprehensive schools, which combine different tracks (Gesamtschule). ${ }^{2}$

Teachers give individual track recommendations in the fourth grade based on the student's marks and the teacher's subjective evaluation of the children's academic abilities. In most Federal States, these recommendations are not binding and parents' decisions regarding which secondary school track to send their children may deviate from the teacher recommendation. In the Federal States where track recommendations are binding, children can still attend a higher track than the one recommended by the teacher, but only if they pass an entrance examination. Although it is theoretically possible for students to change tracks, these changes occur rarely, particularly

\footnotetext{
${ }^{2}$ In the school year 2016/17, $34 \%$ of fifth-graders attended a Gymnasium, $21 \%$ a Realschule, 10 $\%$ a Hauptschule and $31 \%$ a Gesamtschule (Statistisches Bundesamt, 2018, p. 13).
} 
changes to more advanced school tracks (Blossfeld, 2018; Tamm, 2007). Therefore, the initial secondary school track has major implications for access to higher education and the students' later professional career.

In contrast, tracking in Sweden starts after grade nine and there is no between-school tracking in the United States. Compared to Sweden, the United States and most other countries, the German educational system is very rigid and possesses a high level of institutional stratification (Glaesser, 2008). In contrast to the considerations we made above, the early tracking in the German educational system might make parental wealth an important determinant of early educational outcomes in Germany.

\subsection{Distribution of Wealth}

In 2018, the mean household gross wealth in Germany was about 215,000 USD, the median was about 35,000 USD. The mean net worth (assets minus debts) was 184,000 USD. These values are low compared to other European countries and the United States. The level of wealth inequality in Germany (Gini: 0.82; share of the top $10 \%$ of wealth: $58 \%)$ is higher than in Norway $(0.79$; $50 \%)$ but lower than in Sweden $(0.87 ; 67 \%)$ and the United States $(0.85 ; 77 \%)$ (Shorrocks, Davies, \& Lluberas, 2018). Yet, compared to most other European countries, wealth inequality is high in Germany. One reason for this may be that large economic differences persist between East (the former German Democratic Republic) and West Germany. During the time of the German Democratic Republic (1949-90), almost no private capital property existed and the average household wealth is still much lower in East Germany than in West Germany.

The lower end of the net worth distribution in Germany is comprised of $7 \%$ of adults with negative net worth and about $20 \%$ of adults with zero net worth (Grabka, 2015, p. 383). At this point, it is important to consider the ambivalent nature of debts (Hällsten \& Pfeffer, 2017, p. 342). Having large amounts of debt may indicate economic deprivation, but it can also be an indicator of high economic potential. In order to obtain substantial credit, households usually have to provide proof of financial securities, and therefore, assets and debts are usually positively correlated (Brown \& Taylor, 2008). In Germany, this requirement is much stricter as compared to the United States. 
The asset portfolio of all but the wealthiest households is characterized by little variation. The wealth of the households at the lower end of the gross wealth distribution consists mostly of domestic appliances and vehicles. The asset of highest value in the average German wealth portfolio is self-occupied residential property, which accounts for more than $60 \%$ of the total gross wealth (Grabka \& Westermeier, 2014). About $40 \%$ of all German households possess selfoccupied residential property. Although about half of all adults in Germany possess some financial assets and insurance policies, these account for respectively $16 \%$ and $11 \%$ of the total gross wealth. The wealthiest households have asset portfolios that are more diverse. These households also typically hold valuable business assets and non-self-occupied real estate (Skopek, Kolb, Buchholz, \& Blossfeld, 2012). In contrast to other countries, in Germany, household wealth has not been substantially affected by the 2008 financial crisis (Grabka \& Westermeier, 2014).

Typically, wealth has a strong positive correlation with income, education, and occupational class. However, the correlation between wealth and the traditional measures of SES is relatively weak in Germany. The correlation between net worth and income is about 0.30 in Germany (Pfeffer \& Hällsten, 2012, p. 21). In comparison, this correlation is 0.35 in Sweden (Hällsten \& Pfeffer, 2017, p. 355) and ranges between 0.50 and 0.65 in the United States (Killewald, Pfeffer, \& Schachner, 2017, p. 391). Therefore, excluding wealth in research on social stratification in education in Germany may be more problematic than in other countries because income alone is not a good indicator of a household's economic standing with the correlation being comparatively small.

\section{Theory}

\subsection{Competence}

Based on existing research, four interrelated mechanisms may explain the relationship between parental wealth and children's competences. The unit of analysis in this literature is usually the family.

1) Wealth increases resources for families' investment in children. Parents can invest their wealth in the purchase of resources, that foster the competences of their children (Becker \& 
Tomes, 1986). These resources include learning materials (e.g., books or educational software) as well as educational institutions (e.g., child-care facilities and private schools). Other resources in which parents can invest in their children's education are activities that stimulate learning, such as participating in extra-curricular activities, hiring private tutoring lessons and also taking part in cultural activities, like attending concerts or visiting museums (Orr, 2003). For poor families, wealth may enable these families to meet all basic needs of their children (e.g., nutrition, healthcare, and housing conditions) (Bradley \& Corwyn, 2002).

2) Wealth reduces family stress. Economic hardship causes distress, as well as behavioral problems and marital conflict for parents. This reduces the warmth and quality of parenting, which may subsequently slow the competence development of their children (Conger \& Conger, 2002). These adverse effects of economic hardship can be softened by wealth because wealth can be used to smooth consumption in periods of economic difficulties. Even when wealth is not consumed, it can create a sense of economic security, thereby reducing family stress.

3) Wealth facilitates residential segregation. Wealth enables families to live in affluent neighborhoods or to relocate to neighborhoods where kindergartens and schools have more resources (Pfeffer, 2018, p. 1037). Living in these neighborhoods or being enrolled in these institutions may foster children's competence development through positive peer effects or access to higher quality urban amenities (e.g., public parks and libraries) (Owens, 2016).

4) Wealth fosters pro-educational norms and aspirations. Wealth may create a sense of educational entitlement (Conley, 1999, 2001), leading wealthy families to promote proeducational norms among their children. These norms are likely to increase children's motivation for learning and, thereby, lead to higher educational performance (Hällsten \& Pfeffer, 2017). The literature proposes three reasons why wealthier parents are more likely to have pro-educational norms: First, families aim to secure or increase their wealth advantage across generations (Conley, 2001). One way in which families may secure this wealth advantage is through (higher) education and the higher earnings and financial literacy associated with it. Second, families with high economic but low cultural capital might use education as a means to transform or legitimize their economic capital. The need to do so 
arises from the perception that in meritocratic societies, economic advantages achieved through educational attainment are viewed more positively than those achieved through wealth transfers (Bourdieu \& Passeron, 1977). Third, wealth allows families to have a more future-orientated attitude, which is correlated with having higher educational aspirations (Shobe \& Page-Adams, 2001; Zhan \& Sherraden, 2011).

We expect parental wealth to affect investment, family stress, place of residence, and educational aspirations additionally to the effects of parents' education, class, and income. Yet, most of these proposed mechanisms are derived from research done in the United States. While we may assume that the mechanisms work similarly in the German context, they may cause less pronounced differences. German households should be less likely to suffer from severe economic hardship compared to households in the United States due to the more generous welfare state. Therefore, fewer families should be restricted in their investments in children or be affected by constant stress. We expect segregation to be a less relevant factor in Germany because educational resources are less dependent on the neighborhood in Germany than in the United States (Pfeffer, 2011). Lastly, we assume that future orientation to be less stratified by wealth as education is free of tuition fees.

We expect the early tracking in Germany, however, to strongly alter the association between parental wealth and children's early competences. Early tracking may make parents' proeducational norms more salient in the first years of schooling and may increase parents' investment in their children's competences to increase their chances of qualifying for the highest secondary school track.

In summary, we expect to find a positive relationship between parental wealth and children's competences in the early school career in Germany. Moreover, we expect that wealth stratification in competences increases throughout primary school. Pro-educational norms may become more salient the closer the children get to the important transition to secondary school. Thus, when children reach those ages, parents may invest more time and money to realize the high educational aspirations they have for their children. 


\subsection{Transition to Secondary School}

If children in wealthy households have higher competences and perform better in school, they should also be more likely to attend the highest track (i.e., primary effect of parental wealth). Based on previous research on traditional measures of parental SES, we expect children from wealthy families to be more likely to attend this highest track, net of competences and school marks (i.e., secondary effect of parental wealth). Importantly to mention, early educational decisions are more likely to be initiated primarily by the parents, with a less direct influence of the child as compared to later decisions in the child's educational career (Becker \& Hecken, 2009).

Research in Germany found that secondary effects of parents' education and occupational class account for about 40 to $60 \%$ of differences in children's transition rates to the secondary school track (Neugebauer, 2010; Neugebauer, Reimer, Schindler, \& Stocké, 2013). By comparison, in Sweden, most of the differences in educational attainment can be attributed to primary effects of wealth (Hällsten \& Pfeffer, 2017; Hällsten \& Thaning, 2018), while in the United States, the secondary effects of wealth seem to dominate (Elliott et al., 2011).

Secondary effects of parental SES can be explained by the socially stratified expectations of the costs and benefits of the different educational alternatives (Breen \& Goldthorpe, 1997; Erikson \& Jonsson, 1996), or in our case the different secondary school tracks (Becker, 2003; Neugebauer, 2010). Families compare their expected utility from each educational track and choose the track that maximizes it. The subjective expected utility (SEU) model proposes that the utility derived from attending a track depends on the expected benefits $(B)$ of graduating from the specific track, on the expected probability to successfully complete this track and to obtain the expected benefits $(p)$, and on the expected costs of this track $(C)$. Furthermore, parents are assumed to be riskaverse regarding their current socioeconomic status, which translates into educational decisions aimed at avoiding status decline $(S D)$. Children will experience status decline if they do not find a job with a similar occupational prestige as their parents'. For children whose parents have a high occupational class, status decline will occur with a high probability $(q)$, if children do not manage to graduate from the highest secondary school track (Becker, 2003; Breen \& Goldthorpe, 1997). 
Originally, these theories consider the effect of parents' occupational class. We argue that it can be applied in a similar manner to parental wealth. We expect parental wealth to affect the factors of the SEU model systematically and, thus, affect educational decisions:

1) Wealth, like income, decreases the relative costs $(C)$ of schooling. While the direct costs of all school tracks in Germany are similar, the opportunity costs of entering and staying in the highest track are higher because children have to stay in school for more years and cannot earn their living. Wealth allows parents to finance these additional years of schooling without the need for children to earn their living.

2) Wealth could increase the $p$ or reduce its importance for the decision. Before the transition to secondary school is made, wealthy parents are likely to have been able to increase their children's achievement and performance in school by providing them with intellectually stimulating resources. Similarly, wealthy parents may also anticipate the opportunity to invest in children's achievement in the future. For instance, if their child struggles in school because of a lack of specific abilities, wealthier parents can partially compensate for this by investing in private tutoring. Importantly, parents do not actually have to invest their wealth to affect this educational decision. The potential to fall back on their wealth - the insurance function of wealth - may be sufficient to choose a more rewarding but riskier track (Hällsten \& Pfeffer, 2017). For instance, parents know that they could potentially use their wealth to finance the additional year of school for repeating a grade if necessary. This implies that secondary effects of parental wealth are more pronounced for children with medium or low performance in school because parents of high-performing children can be certain that their child will succeed in the highest track independent of their wealth. A so-called compensatory effect of parental background for low-performing children has been found for parents' occupational class (Bernardi \& Boado, 2014), education (Neugebauer, 2010), as well as wealth (Prix \& Pfeffer, 2017).

3) Based on the educational entitlement argument (see section 3.1), we assume that parental wealth increases the $B$ of more advanced educational tracks because these tracks can legitimize the advantages gained through economic capital (Bourdieu \& Passeron, 1977). Moreover, specific asset components of parents' wealth, especially having their own business, may increase the labor market returns for specific educational degrees. For 
instance, the returns to a medical degree are higher when the child can take over their parents' medical practice.

4) Wealth can reduce $q$ for less advanced educational tracks. This should be true under the assumption that parents seek to avoid status decline with respect to their wealth (Conley, 2001). Without obtaining a high educational degree, it is more likely that children will deplete their parents' wealth instead of increasing it.

Parental wealth is thus likely to affect several factors of the SEU model above and beyond the effect of parental occupational class, education, and income. Therefore, we assume that children of wealthy parents are more likely to attend the highest track as compared to children of less wealthy parents, even if these children show similar levels of competences and performance. While most of these considerations for the SEU model are not relevant during the early school career (e.g., opportunity costs only start to become relevant when children are not required to go to school anymore), we assume that parents already anticipate the importance of the initial secondary school track for later educational decisions. Thus, wealth stratification observed at later educational decisions in other countries may be partially shifted to the transition to secondary school in Germany, because of its importance for the educational career of children.

\section{Data, Variables, and Methods}

\subsection{Data}

We use data from the German National Educational Panel Study (NEPS) (Blossfeld, Roßbach, \& von Maurice, 2011) for our empirical analysis. ${ }^{3}$ NEPS provides longitudinal data on educational processes from children's birth until late adulthood by following six different starting cohorts. The NEPS is the only German dataset that includes data about parental wealth and assesses

3 This paper uses data from the National Educational Panel Study (NEPS): Starting Cohort Kindergarten, doi:10.5157/NEPS:SC2:7.0.0. From 2008 to 2013, NEPS data was collected as part of the Framework Program for the Promotion of Empirical Educational Research that is funded by the German Federal Ministry of Education and Research (BMBF). As of 2014, NEPS is carried out by the Leibniz Institute for Educational Trajectories (LIfBi) at the University of Bamberg in cooperation with a nationwide network. 
children's competences via standardized tests. This allows us to trace children's competence development and educational transitions using a large number of observations over time. For our analyses, we make use of the kindergarten cohort. The target population of this cohort was children attending kindergarten two years prior to their enrollment in elementary school in Germany in 2010/11. After kindergarten, children are followed throughout primary and secondary school. The sample was extended when children started attending primary school. By the time the most recent panel wave took place (wave seven: 2016/17), most children had reached fifth grade, which means that they had just made the transition to secondary school.

For our analyses, we include all children who participated in all three math tests in primary school and whose parents had participated in the survey at least once. This left our sample with 4,611 children for the analysis of competences (hereafter "Sample A").

For the analysis of the transition to secondary school, we include all children that had reached secondary school by 2017, excluding those who were attending a special-needs school. If information on the attended secondary school track is not available, we substituted it with the track in which the parents enrolled their children at the end of the fourth grade. Additionally, the parents of these children have to have participated in the survey at least once. This left us with a sample of 4,572 children for the analysis of the transition to secondary school (hereafter "Sample B"). ${ }^{4}$

\subsection{Variables}

\section{Competence}

We operationalize our first outcome of interest using math competence test scores on standardized tests which contained between 22 and 24 items (for details, see Neumann et al., 2013). The tests took place on three occasions: in 2013 when children were enrolled in the first grade; then again in 2014 when children were in the second grade; and finally in 2016 when children had reached the fourth grade. We chose math competence for two reasons. First,

\footnotetext{
${ }^{4}$ It is important to note that these two samples differ. Information about secondary school track is missing for some children who participated in all math competence tests and vice versa. We can only use 3,262 children in both analyses. Our substantive results do not change when we run the analyses only with this sub-sample.
} 
previous research showed consistent findings for the relationship between parental wealth and competences only for math (Elliott et al., 2011). Using math competences thus makes it easier to compare our results to those of previous research. Second, only math competences have been measured in the NEPS at least three times throughout primary school, and thus, allow us to study changes over time. However, as a robustness check, we ran our analysis also for test scores in grammar, natural sciences, and reading.

To derive an estimate of the unobserved competence of the children from the test results, we used the weighted maximum likelihood estimates (WLE) provided by NEPS (Warm, 1989). We standardized WLEs for the analysis sample to have a mean of zero and a standard deviation of one for ease of interpretation.

\section{Secondary School Track}

Our second outcome of interest is the secondary school track attended by children in the fifth grade. We distinguish between the highest track (Gymnasium) and all other tracks. We chose this operationalization because Gymnasium is the only track common to all Federal States and is the only track granting direct access to higher education.

\section{Parental Wealth}

In NEPS, parental wealth was measured when children were in the second grade during the year 2014. In a first step, NEPS participants were asked whether their household ${ }^{5}$ possesses different kinds of assets: savings books and checking accounts; building loan agreements; life insurances and private pension insurances; fixed-interest securities; other securities such as stocks, funds, bonds; business assets; owner-occupied real estate property; and other real estate property. In a second step, participants were asked to report the total value of all these assets and the total value

${ }^{5}$ We are most likely underestimating the importance of parental wealth for children who are not living with both of their parents in a household. The absent parent can be expected to invest his or her wealth in the child's education, too. 
of all their liabilities. ${ }^{6}$ When respondents did not report a value, they were asked to pick range categories that capture the values of their assets and debts.

In line with previous research, we use parents' net worth as a measure of wealth. Given that the distribution of net worth is highly skewed, we transformed our variable's distribution using an inverse hyperbolic sine transformation (Friedline et al., 2015). Moreover, exploratory analysis of the distribution of wealth revealed a non-linear association between categories of net worth and our outcome variables. Five polynomials of the transformed net worth were included to approximate this non-linear association, which also helped to reduce the leverage of outliers.

\section{Parental SES and Further Controls}

To account for the effect of other measures of parents' SES, we included parents' income, education, and occupational class in our analysis. Income was measured at the household level. We converted this variable into income quintile categories. We use the International Standard Classification of Education (ISCED) to measure parents' education. We use the EGP to measure occupational class. Following Erikson's (1984) dominance coding strategy, we use the highest value of the parents' ISCED and EGP to classify the household.

Furthermore, we control for potential confounders of the association between parents' wealth and children's educational outcomes. On the parental level, we use employment status, family status, mother tongue, and age. On the child level, we use the sex, age, number of siblings, whether the child lives with both biological parents, migration status, and whether the child lives in East or West Germany.

\subsection{Imputation of Missing Data}

We applied multiple imputation to deal with missing values. On average, $14 \%$ of the independent variables in sample A and $11 \%$ of the independent variables in sample B were

6 Thus, NEPS uses a similar procedure to assess wealth as, for example, the German SocioEconomic Panel (SOEP), but with less details. Most importantly, NEPS only asks for the total value of all assets and not for the value of the different components and NEPS asks for household wealth instead of individual wealth. The average net worth of households in the SOEP who had a child in elementary school in 2012 is slightly lower than in NEPS but the distribution is similar otherwise. 
missing. One reason for this high share of missing values is that parents did not participate in all panel waves. Additionally, parents did not answer all questions or did only provide rough categories regarding their assets, debts and income. Most item non-response occurred for parents' assets (36 \% missings in sample A, $33 \%$ in sample B) and debts (22\% missings in sample A, 19 $\%$ in sample B).

We imputed missing values using chained equations to reduce the bias caused by systematic nonresponse and to increase the statistical power of our analysis. We impute all missing values using only cases that have no missing values in the respective dependent variable for our analysis (Von Hippel, 2007). Following the approach of Burgette \& Reiter (2010), we use categorization and regression trees (CART) for imputation. CART is a nonparametric recursive algorithm that uses binary splits to create groups with maximum intragroup homogeneity and minimum intergroup homogeneity. We stop the algorithm when groups become smaller than 50 cases (Aßmann, Würbach, Goßmann, Geissler, \& Bela, 2017; Burgette \& Reiter, 2010). Using CART for multiple imputation has the advantage that the algorithm finds the best predictors among all potential covariates, including non-linear patterns and interactions. Imputation values are drawn from the terminal nodes of the trees. This means that we replace missing values using values that have been observed for other households with similar characteristics. In our imputation model, we include all the covariates that we will use in our analyses. We also include time-varying control variables measured in 2015 and 2017, the variables measuring the existence of different kinds of assets, results of other competence tests, and the meta-data about the interviews to get plausible imputations. If information about the range categories about assets, debts or income is available and the imputed values fall outside these specified ranges, we set the imputed values to the lower or upper limit of the category. We create 100 imputed data sets and report average across all imputed datasets and apply Rubin's rules to obtain standard errors in the results section (Rubin, 1987).

\subsection{Methods}

We estimate two separate models: one for the association between parents' wealth and children's test scores in math (using sample A) and one for the association between parents' wealth and children's secondary school track (using sample B). Given that our data consists of repeated measures on the child's competence, we estimate a generalized linear mixed model with random- 
effects for the child to evaluate the association between parental net worth and children's competence development. To predict a child's math competence, we include parental net worth and the control variables mentioned above. We also include an interaction term between year and parental net worth in order to examine whether the association between net worth and test scores varies over time.

Second, to assess the association between parental net worth and secondary school track, we apply two logistic regression models. Here, the outcome variable captures whether the child attends a Gymnasium or not. In a first step, we include parental net worth and all control variables. For all time-varying variables, we use the values measured in 2016. In a second step, we add math and reading competences and marks in math and German in the fourth grade to assess secondary effects of parental wealth. We present our results as the predicted probabilities to attend a Gymnasium. Predicted probabilities are generated for all individuals conditional on their observed values on control variables and are then averaged. Contrary to logistic regression coefficients, predicted probabilities are comparable across nested models and allow us to estimate the relative importance of primary and secondary effects (Breen, Karlson, \& Holm, 2018).

\section{Results}

\subsection{Descriptive Statistics}

Table 1 shows the distribution of all the variables used in our analyses. The first three columns show the summary statistics of the variables used in the analysis of test scores (sample A), separately for each year in which a test in math took place. In sample A, parental net worth ranges from $-3.75 \mathrm{~m}$ EUR to $195 \mathrm{~m}$ EUR, with the second-highest value being $16 \mathrm{~m}$ EUR. The mean of net worth in sample A is 195k EUR and the median is 100k EUR. About $9 \%$ of the households in sample A have a negative net worth, $6.5 \%$ of the households have a net worth of exactly zero. Only $6.2 \%$ of the households report net worth above 500k EUR (for a more detailed picture of the net worth distribution see Figures S1 and S2 in the online supplements). The Gini coefficient of net worth in sample A is 0.70 and the wealthiest $10 \%$ of the households hold around $48 \%$ of the total net worth. Thus, net worth is more equally distributed in our sample as compared to the overall German population. Moreover, we see that household income increases and parents move into higher occupational classes over the years. 
The last column shows the summary statistics of the variables used in the analysis of Gymnasium attendance (sample B). The average net worth is higher than in sample A (mean: 246k EUR; median: 109k EUR) and net worth is more unequally distributed (Gini: 0.74; share of wealthiest $10 \%: 56 \%$ ) because of selective panel attrition. Additionally, there is a higher social selectivity in Sample B, with more highly educated parents and parents in higher occupational classes as compared to Sample A.

[Table 1 over here]

In line with previous research, we find that the correlations among income, education and occupational class are higher than the correlation of net worth with each of these measures. The rank correlation between net worth and education as well as occupational class is 0.27 and 0.24 , while the rank correlation between income and these measures is 0.48 and 0.44 (for Sample A, for all correlations see tables S1 and S2 in the online supplements). The correlation between net worth and income is about 0.36. Thus, we claim that income alone does not fully capture the economic resources of a household.

\subsection{Math Competence}

Figure 1 shows the predicted values of our random-effects linear regression of math competence in the first, second and fourth grade on parental net worth and the control variables (see Table S3 in the online supplements for the underlying regression estimates). ${ }^{7}$ The $95 \%$ confidence intervals of the predicted values are indicated by the vertical lines. A math competence level of zero, indicated by the horizontal dashed red line, stands for average math competence. The figure reveals three important findings:

${ }^{7}$ Without adjusting for covariates the differences by parental net worth are about 2.5-times the size of the differences reported here. The functional form of the association remains the same, only the disadvantage of children in very wealthy households disappears (see figure A1 in the appendix). The same holds for the association between parental net worth and transition to Gymnasium.

Some of these control variables could be affected by parental wealth, and, therefore, may introduce overcontrol-bias to our results. For instance, some households may generate a part of their income through yields of their stocks. Differences in educational outcomes by parental wealth become slightly stronger when we exclude these variables, but the general pattern remains the same. 
First, there is a distinct association between parents' wealth and their children's math competences in primary school in Germany, even when we control for the traditional measures of parental SES. We find that children in households with zero or small amounts of negative net worth perform worst; their average math test score in the first grade is about 0.10 standard deviations (hereafter SD) below the average test score $(\mathrm{p}<0.05)$. Children in households with a moderately high net worth (between 100k EUR and 300k EUR) perform best; their average math test score is about $0.05 \mathrm{SD}$ above the average test score $(\mathrm{p}<0.05)$ in the first grade. Compared to other components of parents' SES, differences in math test scores by parental net worth are of medium size. The difference in math competence between the worst- and best-performing children by parental net worth $(0.15 \mathrm{SD})$ is larger than the largest competence level difference by parents' occupational class (0.09 SD) as well as by parents' income (0.07 SD). However, the strongest predictor of children's math competences in primary school is parental education. The difference between parents with the lowest education compared to parents with the highest education is more than $0.50 \mathrm{SD}$ (see Table A1 in the Appendix).

Second, the association between parental net worth and children's math test scores is non-linear. Children in households with a high negative net worth show higher test scores than children in households with low negative or zero net worth. For instance, in the first grade, children in households with very high net worth have slightly better than average test scores in math, while children in households with low negative net worth show a below-average test score. For households with a net worth between zero and about 100k EUR, we see a monotone increase in children's test scores with increasing parental wealth. For children in households between about 100k EUR and 300k EUR net worth, we see few differences in test scores by wealth. Children in households with even more net worth perform worse. For instance, in the first grade, the average test score of children in households with a net worth of $1 \mathrm{~m}$ EUR is about 0.09 SD lower than the average test score of children in households with 300k EUR net worth $(p=0.03)$. However, note that the predicted values for children with high negative or high positive net worth are imprecise.

Third, the association between parental wealth and children's math test scores remains rather constant throughout primary school (see Figure A1 in the appendix for the results without the interaction between net worth and year). Our estimates point towards a slightly bigger disadvantage of children in households with a low negative or low positive net worth in the fourth grade as compared to the first and second grade. The average test scores in math of 
children in households with zero or low negative net worth are about 0.20 SD lower than the average test scores of children in moderately wealthy households in the fourth grade. The disadvantage of children in very wealthy households as compared to children in moderately wealthy households becomes smaller in the fourth grade. The difference between children in households with 300k EUR and children in households with 1m EUR net worth shrinks from $0.09 \mathrm{SD}(\mathrm{p}=0.03)$ in the first grade to $0.03 \mathrm{SD}(\mathrm{p}=0.41)$ in the fourth grade. However, these changes are not of noticeable size, nor are they statistically significant.

[Figure 1 over here]

We find similar results for test scores in grammar in the first grade; for natural sciences in the first and third grades; and for reading in the fourth grade (see figure A2 in the appendix). The differences by wealth are slightly smaller for these measures. Yet, these differences are statistically significant with the exception of effects in the competence in natural sciences among first graders.

As already mentioned above, debts have an ambivalent nature, as they can indicate both economic deprivation and economic potential. To find out, whether the non-linear association between net worth and test scores in Figure 1 is driven by the ambivalent nature of debts, we separate net wealth into gross wealth and gross debts and run our analyses again (see figure A3 the in appendix). For gross wealth, we find a similar picture as for the positive value of net worth: Children in households with zero or very low gross wealth perform worst. Afterward, test scores increase with higher levels of wealth but the effect levels off for children in moderately wealthy households. For gross debts, we find that children in households with relatively small levels of debt perform substantially worse than children in households with no debts; and worse than children in households with very high amounts of debts.

Lastly, we try to find out, whether the association between wealth and math test scores is driven by a specific wealth component. While we do not have information about the value of the different wealth components, we do know which assets a household possesses, and use this to infer the effects of specific components of wealth. We find that it is especially the small group of children in households without a savings book or checking account who perform substantially worse $(-0.24 \mathrm{SD}, \mathrm{p}<0.01)$, while children whose parents own their house or apartment score on average 0.08 SD higher $(\mathrm{p}=0.01)$ than children whose parents do not own their home (see Table 
A2). Financial assets seem to be less relevant. Children in households with fixed interest securities (0.05 SD, $\mathrm{p}=0.21)$ or those with stocks, funds or bonds (0.05 SD, $\mathrm{p}=0.07)$ seem to have slightly higher math competences than children in households without these assets.

\subsection{Transition to Secondary School}

We expect the wealth-based differences in children's math competence to translate into wealthbased differences in children's likelihood of attending the Gymnasium. Figure 2 shows the predicted probabilities of attending a Gymnasium by parental wealth with $95 \%$ confidence intervals indicated by the vertical lines. The estimates presented with black dots and lines are based on a logistic regression of Gymnasium attendance on parental net worth and the control variables (see Table S4 in the online supplements for the underlying regression estimates). The blue diamonds and lines show the predicted probabilities when math and reading competences, as well as teacher assigned marks in math and German are controlled for (thus, secondary effects of parental net worth). The dashed red line shows the average probability of Gymnasium attendance in our analysis sample $(61.7 \%)$.

The relation between parental wealth and Gymnasium attendance exhibits a similar pattern to the one we found between parental wealth and math test scores. Children in households with low levels of negative net worth or net worth equal to zero have the lowest predicted probability of attending a Gymnasium. The predicted probability of children in households with zero net worth is only about $55.7 \%$. Thus, their probability to attend a Gymnasium is about 5.5 percentage points lower than the average $(\mathrm{p}<0.01)$. Children in households with about 150k EUR have the highest chances to attend a Gymnasium with a predicted probability of slightly above $64 \%$. The gradient by wealth is rather flat around this part of the distribution.

As for math competence, we see that children in households with high negative net worth and children in households with the highest positive net worth deviate from the linear trend of Gymnasium attendance. For instance, the predicted probability to attend a Gymnasium of children in households with a net worth of $-100 \mathrm{k}$ EUR is average. At the other end of the wealth distribution, children in very wealthy households are even slightly less likely to attend a Gymnasium as compared to the average. Again, note that the estimates are imprecise at both ends of the wealth distribution. 
Compared to the difference in Gymnasium attendance based on parents' education, occupational class, and income, the difference in attendance rates that is associated with parental wealth is moderate. Again, parental education is by far the best predictor of our outcome (see Table A3). Children whose parents have an advanced research qualification (ISCED 6) are almost 40 percentage points more likely to attend a Gymnasium than children whose parents have lower secondary education or less (ISCED 2 or less). Yet, the nine percentage points difference found for parental wealth between about zero and 150k EUR is similar to the difference between upper service class and working class.

The difference in Gymnasium attendance by parental wealth shrinks when we control for the competences and marks in the fourth grade. For instance, the predicted probability of children in households with zero net worth increases from about $55.7 \%$ to $58.6 \%$, while the predicted probability of children in households with a net worth of 100k EUR decreases from $64.3 \%$ to $63.1 \%$. Yet, the 4.5 percentage points difference between these children is still statistically significant $(\mathrm{p}=0.02)$. On average, differences in competences and marks account for about half of the total difference in Gymnasium attendance by parental wealth. We interpret this as evidence for a distinct secondary effect of parental net worth at the transition to secondary school.

[Figure 2 over here]

In line with previous research, we find that secondary effects of parental wealth are slightly more pronounced for children with below-average marks. These results suggest that students from households with small negative or zero net worth are less likely to attend a Gymnasium in all marks categories, but this relation is more pronounced among students with satisfactory or worse marks (see figure A4 in the appendix). This may indicate that parents of "poor performing" children may use their wealth to compensate for their children's disadvantage in performance. However, these results should be interpreted with caution because the subgroups become rather small.

\section{Discussion}

In this paper, we investigated the association between parental wealth and (1) children's competence, operationalized as test score results in math at the beginning of primary school; (2) 
the development of children's math competence throughout primary school; and (3) children's educational transition to secondary school, operationalized as attendance to the highest secondary school track.

In line with prior research, we find that even after controlling for traditional measures of SES, parental wealth has a distinct association with children's math competence. While most previous research focused on wealth effects for older children, we found that an association already exists for children in primary school in Germany. These wealth-driven differences in children's math competence might be the result of the early tracking component of the German educational system. Such a system incentivizes parents to invest their wealth early on in their children's competence so as to secure the opportunity for their children to attend the highest secondary school track.

Our results suggest that there is a non-linear association between parental net worth and children's competence. Children in households with high negative parental net worth perform better in math tests than children in households with low negative or zero net worth. A potential explanation for the educational disadvantage of children in households with a low negative net worth (compared to those in households with positive net worth) is that the low negative net worth was caused by having unsecured debts, which can have a negative effect on children's competence (Williams Shanks, 2007). Families who have unsecured debts and, hence, struggle to make ends meet, will probably also have trouble in providing a pro-learning environment to their children at home. In additional analyses, we found that it is especially the small group of children in households without a saving book or checking account who perform substantially worse. These children are very likely to suffer from liquidity constraints if their parents do not have these common types of assets.

Children in households with high negative net worth fare somewhat better than children in households with low negative net worth. But this is probably due to these household's high levels of negative net worth as reflection of their good financial position. These households might have secured debts that are backed up by strong financial credit. In order to take out a large loan in Germany, households have to provide proof of a high level of financial securities. Thus, having high negative net worth in Germany may indicate high economic potential instead of economic 
disadvantage. Hällsten \& Pfeffer (2017) find a similar pattern for the relationship between parental wealth and children's GPA in the ninth grade for Sweden.

The best performance is shown by children with medium to high parental net worth. Intriguingly, children in households with very high parental wealth tend to perform worse than children in households with medium or high parental wealth. This contrasts with previous findings for other countries. However, in our sample, there are few households with these high amounts of net worth. Further research is needed to establish whether wealthy households have worse educational outcomes in the early school career, and if so to investigate why this could be the case; or to establish if this is just an artifact in the data.

Contrary to our expectations, we found the association between parental wealth and math test scores to remain stable throughout primary school. One explanation for the stable association may be that the time interval we examine is too short to reveal noticeable changes. An alternative explanation may be that important investments took place before primary school, such as improving the children's learning environment or moving to a neighborhood with better schools. Finally, schooling may also decrease wealth disparities in competences because it provides all students with a standardized learning environment (Downey \& Condron, 2016).

Investigating the transition from primary to secondary school, we found a small but distinct association between parental wealth and children's probability of attending a Gymnasium. Children in wealthier households are more likely to attend a Gymnasium. However, like for competences, we see a non-linear association, where children in households with high negative and very high positive net worth deviate from the trend in the middle of the wealth distribution. The differences by parental wealth can be attributed in roughly equal parts to differences in competences and performance by parental wealth (primary effect of parental wealth) and to differences in educational decisions (secondary effect of parental wealth).

Similar to Pfeffer (2011), we found that parents' education is by far the strongest predictor of math competence and Gymnasium attendance. Differences by parental wealth are of similar size as differences by parental occupational class or income. Compared to the results found for the US, we find smaller associations between wealth and test scores (Friedline et al., 2015; Yeung \& Conley, 2008). The differences in secondary school track transition rates by parental wealth in Germany are of a similar magnitude to those found for Sweden (Hällsten \& Thaning, 2018) and 
only slightly smaller than the ones found for the United States (Pfeffer, 2018). It might be the case that the wealth stratification which was observed at later educational decisions in other countries is partially shifted to the transition to secondary school in Germany, because of its importance for the further educational career of children. Yet, these comparisons should be interpreted with caution because of other differences between the studies and that no prior tracking took place in these countries.

Some limitations should be considered in interpreting our results. Parental wealth was only measured once in NEPS. Therefore, wealth may be measured with error (Goodman \& Ittner, 1992) and we are unable to detect whether household wealth changed over time. According to data from the German Socio-Economic Panel Study, wealth remained rather stable throughout the five years (2013-17) of our study (Grabka \& Westermeier, 2014). Yet, some families may have experienced greater wealth increases than others, for instance, families with real estate in urban areas affected by gentrification. Measurement error and treating wealth as time-constant may lead to an underestimation of the impact of wealth in our analysis. However, we assume that shortterm changes in wealth are less relevant for educational achievement and attainment as compared to wealth held by families during their children's early childhood years (Cesarini et al., 2016; Hällsten \& Pfeffer, 2017).

Furthermore, unobserved factors may confound the association between parental wealth and children's educational outcomes. For instance, parents' cognitive and non-cognitive competences probably affect both their levels of wealth and their children's educational outcomes (Doren \& Grodsky, 2016); but those were not measured in the NEPS. Therefore, our results may be upwardly biased and should not be interpreted as causal estimates. However, we assume that a big part of parents' competences may be captured by their educational achievement, as well as their income. Even if there was a strong partial correlation of these unmeasured confounders with parental wealth and children's test scores, we would observe smaller, but still statistically significant differences by parental wealth. Therefore, despite these limitations, we interpret our results as support for our claim that wealth is a distinct dimension of social stratification that contributes to social inequality in education over and above the traditional measures of parental SES in Germany. 
We see two open questions remaining in the study of parental wealth effects of children's educational attainment. First, we only considered the association at an early stage in the children's educational careers. Especially regarding educational decisions, we expect that parental wealth would have a stronger effect at later stages because financial considerations should become more relevant at that time. While the financial costs of attending the different secondary school tracks are similar, there are bigger differences in financial costs when students have to choose between going to university or entering the labor market (Becker \& Hecken, 2009). Thus, the secondary effects of parental wealth can be expected to increase at later stages of children's educational careers.

Second, more research is needed to uncover the mechanisms that drive the association between parental wealth and children's educational outcomes. In the theoretical part of our paper, we propose several such mechanisms. Family investment, family stress, residential segregation, and educational entitlement can be considered as potential causal mechanisms; and we proposed that differences in family's expected utilities could explain children's educational decisions. We encourage future research to examine these mechanisms. Knowledge of these will allow us to propose policy interventions that can more effectively reduce social inequality in education.

\section{References}

Aßmann, C., Würbach, A., Goßmann, S., Geissler, F., \& Bela, A. (2017). Nonparametric Multiple Imputation for Questionnaires with Individual Skip Patterns and Constraints: The Case of Income Imputation in the National Educational Panel Study. Sociological Methods \& Research, 46(4), 864-897. https://doi.org/10.1177/0049124115610346

Becker, G. S., \& Tomes, N. (1986). Human Capital and the Rise and Fall of Families. Journal of Labor Economics, 4(3), 1-39. https://doi.org/10.1086/298118

Becker, R. (2003). Educational Expansion and Persistent Inequalities of Education: Utilizing Subjective Expected Utility Theory to Explain Increasing Participation Rates in Upper Secondary School in the Federal Republic of Germany. European Sociological Review, 19(1), 1-24. https://doi.org/10.1093/esr/19.1.1

Becker, R., \& Hecken, A. E. (2009). Higher Education or Vocational Training? An Empirical Test of the Rational Action Modelof Educational Choices Suggested by Breen and Goldthorpe and Esser. Acta Sociologica, 52(1), 25-45. https://doi.org/10.1177/0001699308100632

Bernardi, F., \& Boado, H. C. (2014). Previous school results and social background: Compensation and imperfect information in educational transitions. European Sociological Review, 30(2), 207-217. https://doi.org/10.1093/esr/jct029 
Blau, P. M., \& Duncan, O. D. (1967). The American Occupational Structure. New York, NY: Wiley.

Blossfeld, H.-P., Roßbach, H.-G., \& von Maurice, J. (2011). Education as a Lifelong Process (NEPS). Zeitschrift für Erziehungswissenschaft, 14. https://doi.org/10.1007/s11618-011-0179-2

Blossfeld, P. (2018). Social Background and Between-track Mobility in the General Education System in West Germany and in East Germany after German Unification. Zeitschrift für Soziologie, 47(4), 255-269. https://doi.org/10.1515/zfsoz-2018-0117

Boudon, R. (1974). Education, Opportunity and Social Inequality: Changing Prospects in Western Society. New York, NY: Wiley.

Bourdieu, P., \& Passeron, J.-C. (1977). Reproduction in education, society and culture. London, U.K.: Sage Publications.

Bradley, R. H., \& Corwyn, R. F. (2002). Socioeconomic Status and Child Development. Annual Review of Psychology, 53(1), 371-399. https://doi.org/10.1146/annurev.psych.53.100901.135233

Breen, R., \& Goldthorpe, J. H. (1997). Explaining educational differentials: Towards a formal rational action theory. Rationality and Society, 9(3), 275-305.

https://doi.org/10.1177/104346397009003002

Breen, R., Karlson, K. B., \& Holm, A. (2018). Interpreting and Understanding Logits, Probits, and Other Nonlinear Probability Models. Annual Review of Sociology, 44(1), 39-54.

https://doi.org/10.1146/annurev-soc-073117-041429

Brown, J. R., Coile, C. C., \& Weisbenner, S. J. (2010). The Effect of Inheritance Receipt on Retirement. The Review of Economics and Statistics, 92(2), 425-434.

https://doi.org/10.1162/rest.2010.11182

Brown, S., \& Taylor, K. (2008). Household debt and financial assets: Evidence from Germany, Great Britain and the USA. Journal of the Royal Statistical Society: Series A (Statistics in Society), 171(3), 615-643. https://doi.org/10.1111/j.1467-985X.2007.00531.x

Burgette, L. F., \& Reiter, J. P. (2010). Multiple Imputation for Missing Data via Sequential Regression Trees. American Journal of Epidemiology, 172(9), 1070-1076.

https://doi.org/10.1093/aje/kwq260

Cesarini, D., Lindqvist, E., Östling, R., \& Wallace, B. (2016). Wealth, health, and child development: Evidence from administrative data on Swedish lottery players. Quarterly Journal of Economics, 131(2), 687-738. https://doi.org/10.1093/qje/qjw001

Conger, R. D., \& Conger, K. J. (2002). Resilience in Midwestern families: Selected findings from the first decade of a prospective, longitudinal study. Journal of Marriage and Family, 64(2), 361-373. https://doi.org/10.1111/j.1741-3737.2002.00361.x

Conley, D. (1999). Being Black, Living in the Red: Race, Wealth and Social Policy in America. Berkeley: University of California Press. 
Conley, D. (2001). Capital for College: Parental Assets and Postsecondary Schooling. Sociology of Education, 74(1), 59-72. https://doi.org/10.2307/2673145

Cunha, F., \& Heckman, J. J. (2008). Formulating, Identifying and Estimating the Technology of Cognitive and Noncognitive Skill Formation. Journal of Human Resources, 43(4), 738-782.

https://doi.org/10.3368/jhr.43.4.738

Doren, C., \& Grodsky, E. (2016). What Skills Can Buy: Transmission of Advantage through Cognitive and Noncognitive Skills. Sociology of Education, 89(4), 321-342.

https://doi.org/10.1177/0038040716667994

Downey, D. B., \& Condron, D. J. (2016). Fifty Years since the Coleman Report: Rethinking the Relationship between Schools and Inequality. Sociology of Education, 89(3), 207-220. https://doi.org/10.1177/0038040716651676

Elliott, W., Destin, M., \& Friedline, T. (2011). Taking stock of ten years of research on the relationship between assets and children's educational outcomes: Implications for theory, policy and intervention. Children and Youth Services Review, 33 (2011), 2312-2328.

https://doi.org/10.1016/j.childyouth.2011.08.001

Elliott, W., \& Sherraden, M. (2013). Assets and educational achievement: Theory and evidence. Economics of Education Review, 33, 1-7. https://doi.org/10.1016/j.econedurev.2013.01.004

Erikson, R. (1984). Social Class of Men, Women and Families. Sociology, 18(4), 500-514. https://doi.org/10.1177/0038038584018004003

Erikson, R., \& Jonsson, J. O. (1996). Explaining class inequality in education: The Swedish test case. In R. Erikson \& J. O. Jonsson (Eds.), Can Education Be Equalized? The Swedish Case in Comparative Perspective (pp. 1-63). Boulder, CO: Westview Press.

Feinstein, L. (2003). Inequality in the Early Cognitive Development of British Children in the 1970 Cohort. Economica, 70(277), 73-97. https://doi.org/10.1111/1468-0335.t01-1-00272

Friedline, T., Masa, R. D., \& Chowa, G. A. (2015). Transforming wealth: Using the inverse hyperbolic sine (IHS) and splines to predict youth's math achievement. Social Science Research, 49, 264-287. https://doi.org/10.1016/j.ssresearch.2014.08.018

Glaesser, J. (2008). Just how flexible is the German selective secondary school system? A configurational analysis. International Journal of Research \& Method in Education, 31(2), 193209. https://doi.org/10.1080/17437270802212254

Goodman, J. L., \& Ittner, J. B. (1992). The accuracy of home owners' estimates of house value. Journal of Housing Economics, 2(4), 339-357. https://doi.org/10.1016/1051-1377(92)90008-E

Grabka, M. M. (2015). Income and wealth inequality after the financial crisis: The case of Germany. Empirica, 42(2), 371-390. https://doi.org/10.1007/s10663-015-9280-8

Grabka, M. M., \& Westermeier, C. (2014). Persistently High Wealth Inequality in Germany. DIW Economic Bulletin, 4(6), 3-15. https://doi.org/10.1007/s11150-013-9229-2 
Hällsten, M., \& Pfeffer, F. T. (2017). Grand Advantage: Family Wealth and Grandchildren's Educational Achievement in Sweden. American Sociological Review, 82(2), 328-360.

https://doi.org/10.1177/0003122417695791

Hällsten, M., \& Thaning, M. (2018). Multiple dimensions of social background and horizontal educational attainment in Sweden. Research in Social Stratification and Mobility, 56, 40-52. https://doi.org/10.1016/J.RSSM.2018.06.005

Huang, J., Guo, B., Kim, Y., \& Sherraden, M. (2010). Parental income, assets, borrowing constraints and children's post-secondary education. Children and Youth Services Review, 32(4), 585-594. https://doi.org/10.1016/j.childyouth.2009.12.005

Jackson, M. V. (Ed.). (2013). Determined to succeed? Performance versus choice in educational attainment. Stanford, California: Stanford University Press.

Jez, S. J. (2014). The Differential Impact of Wealth Versus Income in the College-Going Process. Research in Higher Education, 55(7), 710-734. https://doi.org/10.1007/s11162-014-9332-0

Killewald, A., Pfeffer, F. T., \& Schachner, J. N. (2017). Wealth Inequality and Accumulation. Annual Review of Sociology, 43, 379-404. https://doi.org/10.1146/annurev-soc-060116-053331

Linberg, T., Schneider, T., Waldfogel, J., \& Wang, Y. (2019). Socioeconomic status gaps in child cognitive development in Germany and the United States. Social Science Research, 79, 1-31. https://doi.org/10.1016/j.ssresearch.2018.11.002

Neugebauer, M. (2010). Bildungsungleichheit und Grundschulempfehlung beim Übergang auf das Gymnasium: Eine Dekomposition primärer und sekundärer Herkunftseffekte. Zeitschrift für Soziologie, 39(3), 202-214. https://doi.org/10.1515/zfsoz-2010-0303

Neugebauer, M., Reimer, D., Schindler, S., \& Stocké, V. (2013). Inequality in Transition to Seconday School and Tertiary Education in Germany. In M. V. Jackson (Ed.), Determined to Succeed? Performance versus Choice in Educational Attainment, Stanford: Stanford University Press.

Neumann, I., Duchhardt, C., Grüßing, M., Heinze, A., Knopp, E., \& Ehmke, T. (2013). Modeling and assessing mathematical competence over the lifespan. Journal for Educational Research Online, 5(2), 80-109.

OECD. (2013). The survey of adult skills: Reader's companion. Paris: OECD publ.

Orr, A. J. (2003). Black-White Differences in Achievement: The Importance of Wealth. Sociology of Education, 76(4), 281-304. https://doi.org/10.2307/1519867

Owens, A. (2016). Inequality in Children's Contexts: Income Segregation of Households with and without Children. American Sociological Review, 81(3), 549-574.

https://doi.org/10.1177/0003122416642430

Pfeffer, F. T. (2011). Status Attainment and Wealth in the United States and Germany. In T. Smeeding, R. Erikson, \& M. Jäntti (Eds.), Persistence, Privilege, and Parenting. The Comparative Study of Intergenerational Mobility (pp. 109-137). New York, NY: Russell Sage Foundation. 
Pfeffer, F. T. (2018). Growing Wealth Gaps in Education. Demography, 55(3), 1033-1068.

https://doi.org/10.1007/s13524-018-0666-7

Pfeffer, F. T., \& Hällsten, M. (2012). Mobility Regimes and Parental Wealth: The United States, Germany, and Sweden in Comparison. SOEPpapers on Multidisciplinary Panel Data Research, 500.

Piketty, T., \& Zucman, G. (2014). Capital Is Back: Wealth-Income Ratios in Rich Countries 17002010. Quarterly Journal of Economics, 129(3), 1255-1310.

https://doi.org/10.1093/qje/qju018.Advance

Prix, I., \& Pfeffer, F. T. (2017). Does Donald Need Uncle Scrooge ? Extended-family wealth and children's educational attainment in the United States. In J. Erola \& E. Kilpi-Jakonen (Eds.), Social Inequality Across the Generations (pp. 112-135). https://doi.org/10.4337/9781786432568

Rubin, D. B. (1987). Multiple Imputation for Nonresponse in Surveys. New York: Wiley.

Shobe, M., \& Page-Adams, D. (2001). Assets, Future Orientation, and Well-Being: Exploring and Extending Sherraden's Framework. Journal of Sociology \& Social Welfare, 28(7), 109-129.

Shorrocks, A., Davies, J., \& Lluberas, R. (2018). Global Wealth Databook 2018. Zurich: Credit Suisse Publications.

Skopek, N., Kolb, K., Buchholz, S., \& Blossfeld, H.-P. (2012). Einkommensreich vermögensarm? Die Zusammensetzung von Vermögen und die Bedeutung einzelner Vermögenskomponenten im europäischen Vergleich. Berliner Journal für Soziologie, 22(2), 63187. https://doi.org/10.1007/s11609-012-0185-0

Spilerman, S. (2000). Wealth and Stratification Processes. Annual Review of Sociology, 26, 497524. https://doi.org/10.1146/annurev.soc.26.1.497

Statistisches Bundesamt. (2018). Schulen auf einen Blick Ausgabe 2018. Wiesbaden: Statistisches Bundesamt.

Tamm, M. (2007). Does money buy higher schooling?: Evidence from secondary school track choice in Germany. Economics of Education Review, 27(5), 536-545.

https://doi.org/10.1016/j.econedurev.2007.10.005

Von Hippel, P. T. (2007). Regression with missing Ys: An improved strategy for analyzing multiply imputed data. Sociological Methodology. https://doi.org/10.1111/j.1467-

9531.2007.00180.x

Warm, T. A. (1989). Weighted likelihood estimation of ability in item response theory. Psychometrika, 54(3), 427-450. https://doi.org/10.1007/BF02294627

Wiborg, Ø. N. (2017). Family wealth and school grades in Norway - Exploring how the immediate and extended family's wealth matter for the children's school performance. In J. Erola $\&$ E. Kilpi-Jakonen (Eds.), Social inequality across the generations - the role of compensation and multiplication in resource accumulation. (pp. 136-157). Cheltenham, U.K./Northampton, MA: Edward Elgar Publishing. 
Williams Shanks, T. R. (2007). The Impacts of Household Wealth on Child Development. Journal of Poverty, 11(2), 93-116. https://doi.org/10.1300/J134v11n02_05

Yeung, W. J., \& Conley, D. (2008). Black and Family Wealth. Child Development, 79(2), 303324. https://doi.org/10.1111/j.1467-8624.2007.01127.x

Zhan, M. (2006). Assets, parental expectations and involvement, and children's educational performance. Children and Youth Services Review, 28, 961-975.

https://doi.org/10.1016/j.childyouth.2005.10.008

Zhan, M., \& Sherraden, M. (2011). Assets and liabilities, educational expectations, and children's college degree attainment. Children and Youth Services Review, 33(6), 846-854.

https://doi.org/10.1016/j.childyouth.2010.12.006 


\section{Tables}

Table 1: Descriptive statistics

\begin{tabular}{|c|c|c|c|c|}
\hline & \multicolumn{3}{|c|}{ Competence } & \multirow{2}{*}{$\begin{array}{l}\text { Track } \\
2016\end{array}$} \\
\hline & 2013 & 2014 & 2016 & \\
\hline Math competence & 0.000 & 0.000 & 0.000 & 0.000 \\
\hline Gymnasium & - & - & - & 0.617 \\
\hline Net worth & 195000 & constant & constant & 246000 \\
\hline $\mathrm{HH}$ income & 3930 & 4404 & 4573 & 4852 \\
\hline No full time employment & 0.051 & 0.051 & 0.074 & 0.066 \\
\hline Number of siblings & 1.404 & 1.417 & 1.416 & 1.370 \\
\hline Birthyear of parents & 1973 & constant & constant & 1973 \\
\hline Birthyear of child & 2006 & constant & constant & 2006 \\
\hline Living with biological parents & 0.838 & constant & constant & 0.861 \\
\hline Mothertongue: German & 0.841 & constant & constant & 0.862 \\
\hline East & 0.141 & constant & constant & 0.106 \\
\hline Girl & 0.517 & constant & constant & 0.511 \\
\hline \multicolumn{5}{|l|}{ Income quintile } \\
\hline 1. Quintile & 0.174 & 0.182 & 0.180 & 0.160 \\
\hline 2. Quintile & 0.146 & 0.123 & 0.206 & 0.197 \\
\hline 3. Quintile & 0.254 & 0.277 & 0.159 & 0.150 \\
\hline 4. Quintile & 0.197 & 0.189 & 0.202 & 0.209 \\
\hline 5. Quintile & 0.229 & 0.228 & 0.253 & 0.283 \\
\hline \multicolumn{5}{|l|}{ Highest ISCED } \\
\hline 2 or less & 0.042 & 0.043 & 0.027 & 0.020 \\
\hline 3 & 0.270 & 0.273 & 0.263 & 0.234 \\
\hline 4 & 0.093 & 0.094 & 0.093 & 0.092 \\
\hline $5 B$ & 0.211 & 0.209 & 0.216 & 0.211 \\
\hline $5 A$ & 0.323 & 0.321 & 0.341 & 0.372 \\
\hline 6 & 0.060 & 0.060 & 0.060 & 0.071 \\
\hline \multicolumn{5}{|l|}{ Highest EGP } \\
\hline$I$ & 0.353 & 0.353 & 0.392 & 0.410 \\
\hline II & 0.310 & 0.309 & 0.309 & 0.318 \\
\hline$I I I a, I V$ & 0.153 & 0.153 & 0.158 & 0.147 \\
\hline$I I I b, V, V I, V I I$ & 0.184 & 0.184 & 0.141 & 0.125 \\
\hline \multicolumn{5}{|l|}{ Family status } \\
\hline married & 0.857 & 0.858 & 0.848 & 0.865 \\
\hline divorced or widowed & 0.056 & 0.061 & 0.075 & 0.067 \\
\hline single & 0.087 & 0.081 & 0.076 & 0.068 \\
\hline \multicolumn{5}{|l|}{ Generation status } \\
\hline Native & 0.750 & constant & constant & 0.770 \\
\hline First generation & 0.021 & constant & constant & 0.018 \\
\hline Second generation & 0.196 & constant & constant & 0.179 \\
\hline Third generation & 0.033 & constant & constant & 0.033 \\
\hline $\mathrm{N}$ & 4611 & 4611 & 4611 & 4572 \\
\hline Sample & A & A & A & $\mathrm{B}$ \\
\hline
\end{tabular}


Multiple imputed data $(M=100)$ of NEPS starting cohort Kindergarten. Average values across all imputations. Means for continuous variables and proportions for categorical variables. Categories of categorical variables with more than two values are indented and in italics. "_" means that the variable is not included in the analysis. "constant" means that value does not change over time. 


\section{Figures}

Figure 1: Predicted math competence by parental net worth

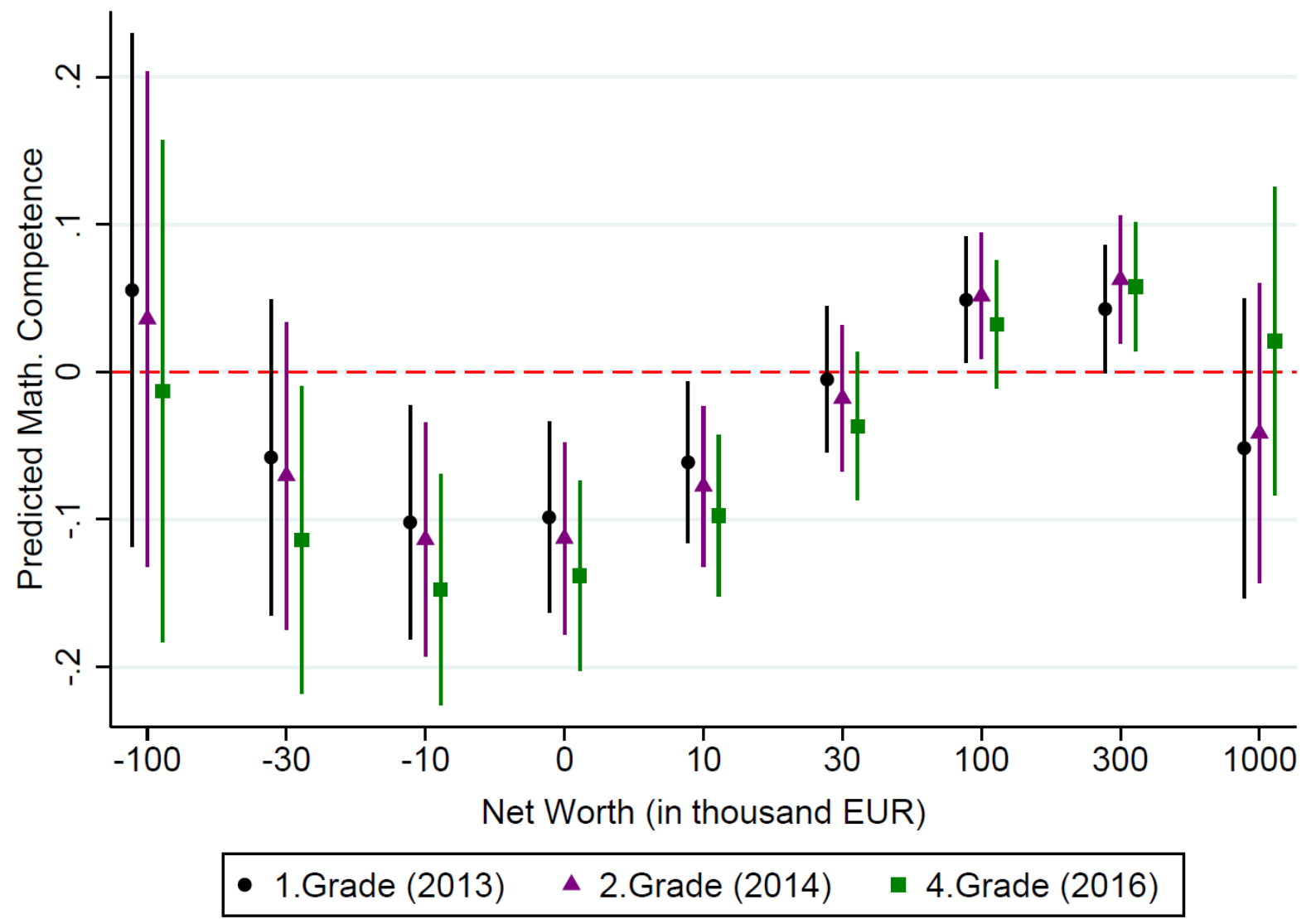

$\mathrm{N}=4,611$. Multiple imputed data $(\mathrm{M}=100)$ of NEPS starting cohort Kindergarten, Sample A. Horizontal lines show 95\%-confidence intervals. 
Figure 2: Predicted probability to attend the highest track by parental net worth

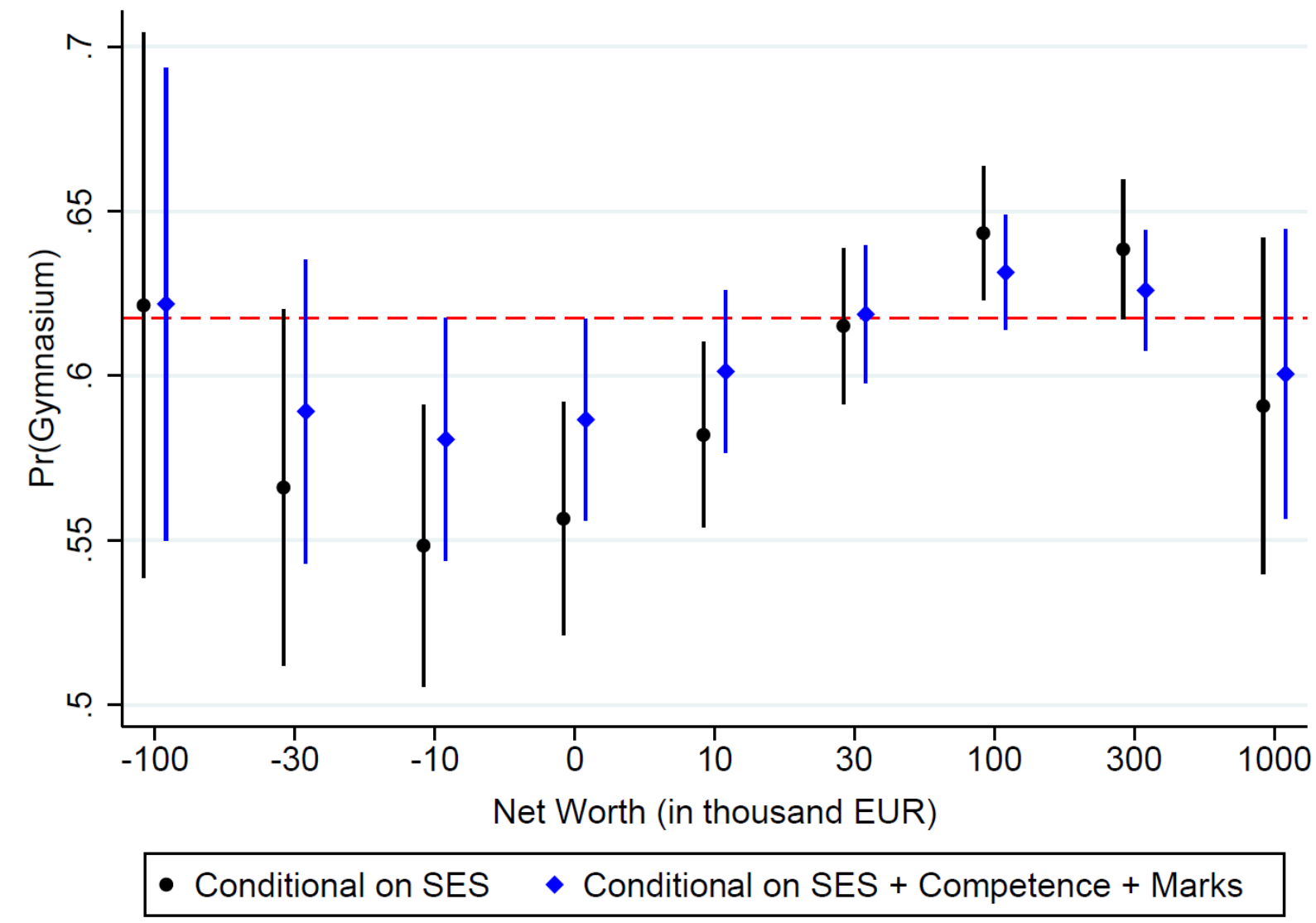

$\mathrm{N}=4,572$. Multiple imputed data $(\mathrm{M}=100)$ of NEPS starting cohort Kindergarten, Sample B. Horizontal lines show 95\%-confidence intervals. 


\section{Appendix}

Table A1: Differences in math competence by parents' income, education, and class (unstandardized coefficients, standard errors in parenthesis)

\begin{tabular}{lll}
\hline & $\mathrm{b}$ & $\mathrm{SE}$ \\
\hline Income & & \\
2. Quintile & -0.027 & $(0.029)$ \\
3. Quintile & -0.003 & $(0.029)$ \\
4. Quintile & 0.040 & $(0.032)$ \\
5. Quintile & 0.046 & $(0.034)$ \\
ISCED & & \\
3 & & \\
4 & 0.057 & $(0.066)$ \\
$5 B$ & $0.200^{*}$ & $(0.078)$ \\
$5 A$ & $0.223^{* *}$ & $(0.076)$ \\
6 & $0.431^{* * *}$ & $(0.076)$ \\
& $0.541^{* * *}$ & $(0.096)$ \\
EGP & & \\
II & & $(0.026)$ \\
IIIa, IV & -0.000 & $(0.032)$ \\
\hline Observations & -0.057 & $(0.037)$ \\
\hline
\end{tabular}

Multiple imputed data $(\mathrm{M}=100)$ of NEPS starting cohort Kindergarten; Sample A. Reference categories: Income: 1. Quintile; ISCED: 2 or less, EGP; I. Significance levels: $* * *=p<0.001$, ** $=\mathrm{p}<0.01, *=\mathrm{p}<0.05,+=\mathrm{p}<0.10$. All control variables are included in the regression. 
Table A2: Random-effects regression of mathematical competence on possession of different kinds of assets (unstandardized coefficients, standard errors in parenthesis)

\begin{tabular}{lll}
\hline & $\mathrm{b}$ & $\mathrm{SE}$ \\
\hline Savings books/checking account & $0.240^{* * *}$ & $(0.064)$ \\
Building loan agreements & 0.013 & $(0.028)$ \\
Life insurances and private pension insurances & 0.034 & $(0.035)$ \\
Fixed-interest securities & 0.049 & $(0.039)$ \\
Other securities such as stocks, funds, bonds & $0.052+$ & $(0.029)$ \\
Business assets & 0.002 & $(0.036)$ \\
Owner-occupied real estate property & $0.079^{*}$ & $(0.031)$ \\
Other real estate property & -0.017 & $(0.034)$ \\
Other assets & -0.010 & $(0.063)$ \\
\hline Observations & 4,611 & \\
\hline
\end{tabular}

Multiple imputed data $(M=100)$ of NEPS starting cohort Kindergarten; Sample A. Reference categories: Income: 1. Quintile; ISCED: 2 or less, EGP; I. Significance levels: $* * *=p<0.001$, ** $=\mathrm{p}<0.01, *=\mathrm{p}<0.05,+=\mathrm{p}<0.10$. All control variables are included in the regression. 
Table A3: Differences in predicted probabilities of Gymnasium attendance by parents' income, education, and class (standard errors in parenthesis)

\begin{tabular}{|c|c|c|c|c|}
\hline & $\begin{array}{l}\text { Model } 1 \\
\text { Difference }\end{array}$ & $\mathrm{SE}$ & $\begin{array}{l}\text { Model } 2 \\
\text { Difference }\end{array}$ & $\mathrm{SE}$ \\
\hline \multicolumn{5}{|l|}{ Income } \\
\hline 2. Quintile & 0.016 & $(0.030)$ & 0.003 & $(0.027)$ \\
\hline 3. Quintile & $0.068^{*}$ & $(0.030)$ & 0.035 & $(0.026)$ \\
\hline 4. Quintile & $0.091^{* *}$ & $(0.029)$ & 0.045 & $(0.026)$ \\
\hline 5. Quintile & $0.137^{* * *}$ & (0.029) & $0.084^{* *}$ & $(0.026)$ \\
\hline \multicolumn{5}{|l|}{ ISCED } \\
\hline 3 & $0.150^{*}$ & $(0.060)$ & 0.097 & $(0.059)$ \\
\hline 4 & $0.247^{* * * *}$ & $(0.064)$ & $0.125^{*}$ & $(0.063)$ \\
\hline $5 B$ & $0.245^{* * *}$ & $(0.062)$ & $0.137^{*}$ & $(0.061)$ \\
\hline $5 A$ & $0.356^{* * *}$ & $(0.063)$ & $0.177^{* *}$ & $(0.062)$ \\
\hline 6 & $0.402^{* * *}$ & $(0.069)$ & $0.184^{* *}$ & $(0.067)$ \\
\hline \multicolumn{5}{|l|}{ EGP } \\
\hline II & $-0.040^{*}$ & $(0.018)$ & $-0.041^{* *}$ & $(0.015)$ \\
\hline$I I I a, I V$ & -0.040 & $(0.024)$ & -0.024 & $(0.020)$ \\
\hline$I I I b, V, V I, V I I$ & $-0.111^{* * *}$ & $(0.029)$ & $-0.061^{*}$ & $(0.024)$ \\
\hline Observations & 4572 & & 4572 & \\
\hline
\end{tabular}

Multiple imputed data $(M=100)$ of NEPS starting cohort Kindergarten; Sample B. Reference categories: Income: 1. Quintile; ISCED: 2 or less, EGP; I. Significance levels: $* * *=p<0.001$, ** $=\mathrm{p}<0.01, *=\mathrm{p}<0.05,+=\mathrm{p}<0.10$. All control variables are included in the regression. 
Figure A1: Predicted math competence by parental net worth

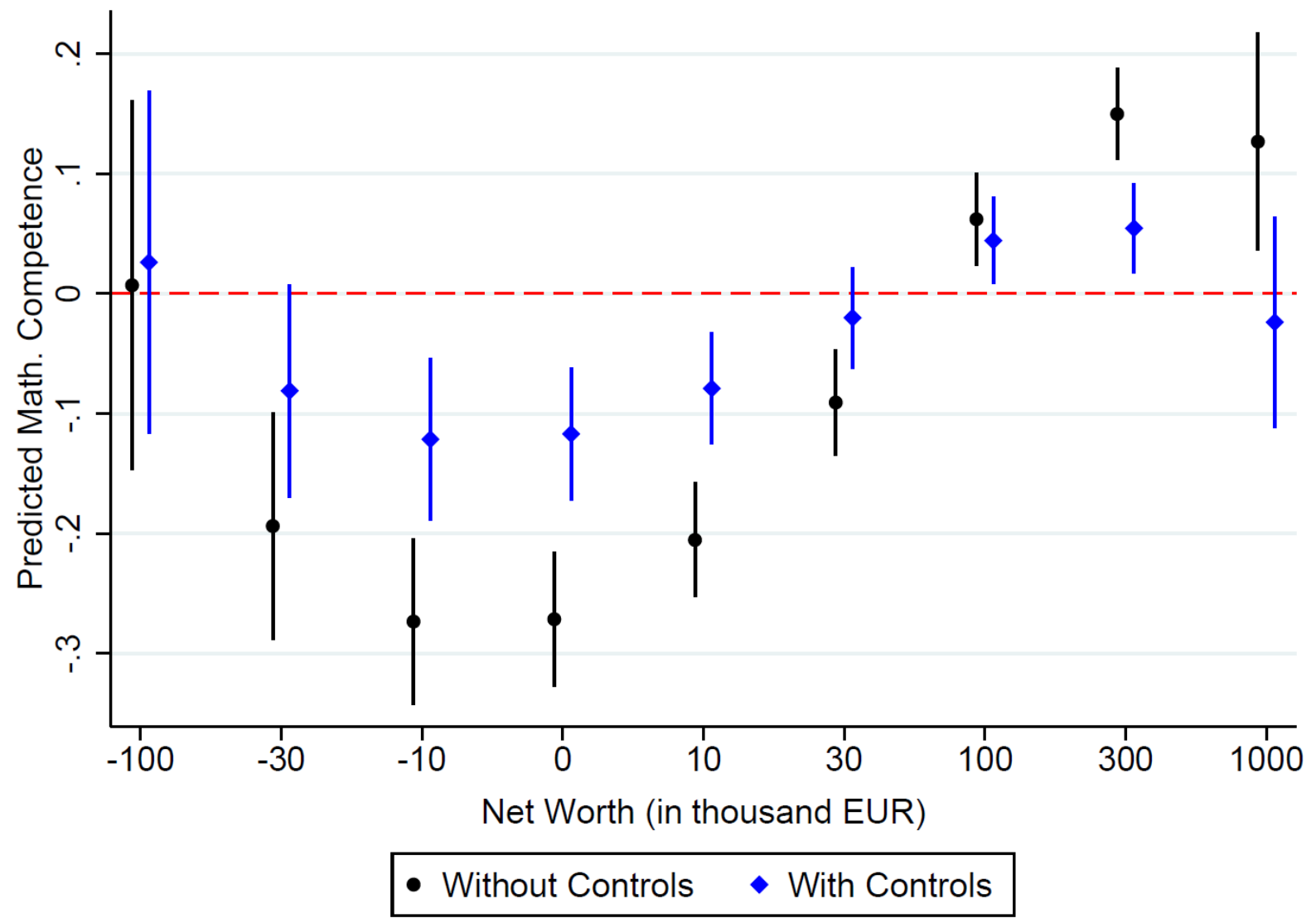

$\mathrm{N}=4,611$. Multiple imputed data $(\mathrm{M}=100)$ of NEPS starting cohort Kindergarten, Sample A. Horizontal lines show 95\%-confidence intervals. 
Figure A2: Predicted grammar, natural science and reading competence by parental net worth

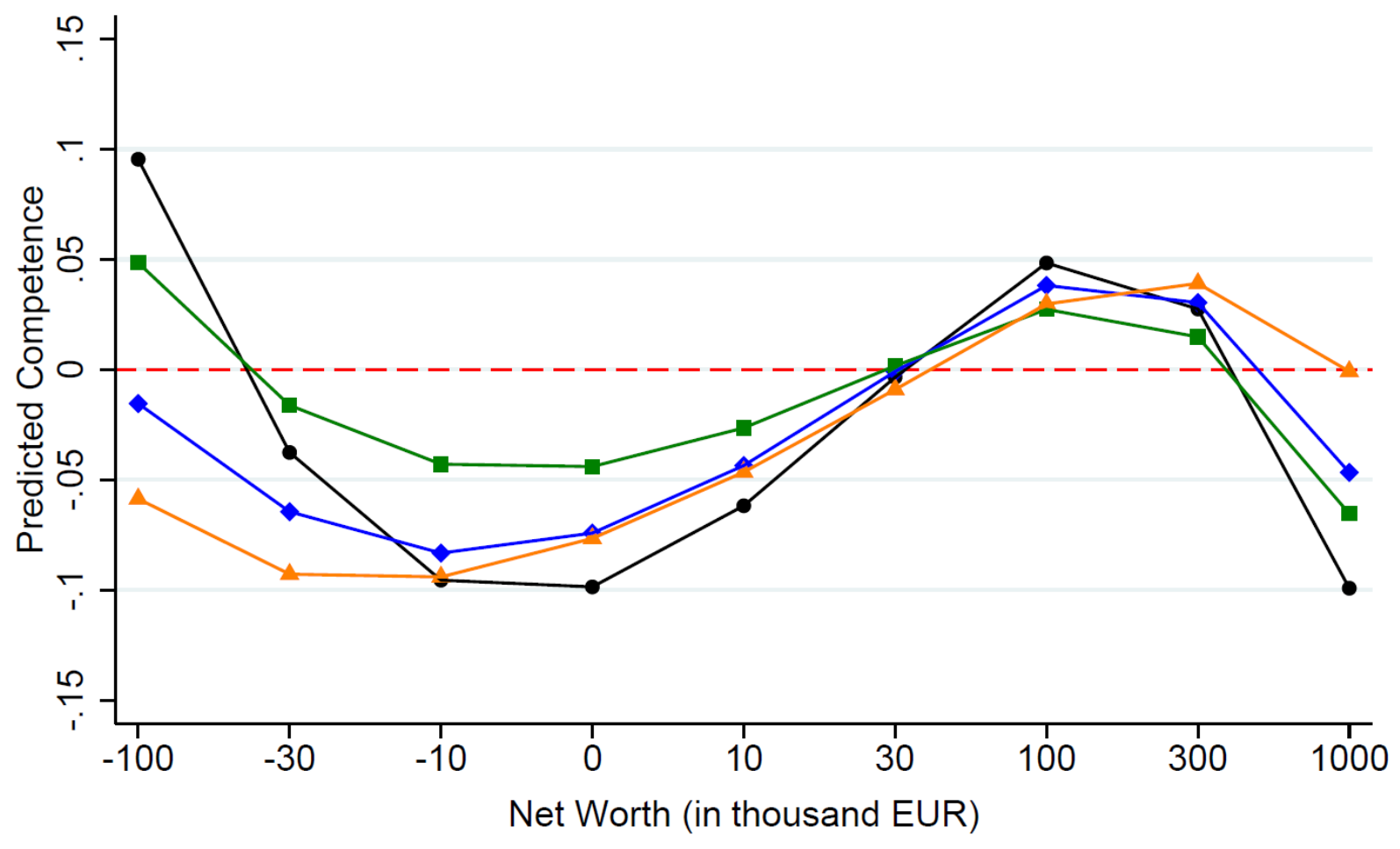

- Grammar (1. Year) • Reading (4. Year)

- Science (1. Year) $\quad$ Science (3. Year)

$\mathrm{N}=4,611$. Multiple imputed data $(\mathrm{M}=100)$ of NEPS starting cohort Kindergarten, Sample A. Horizontal lines show 95\%-confidence intervals. 
Figure A3: Predicted math competence by parental gross wealth and debts

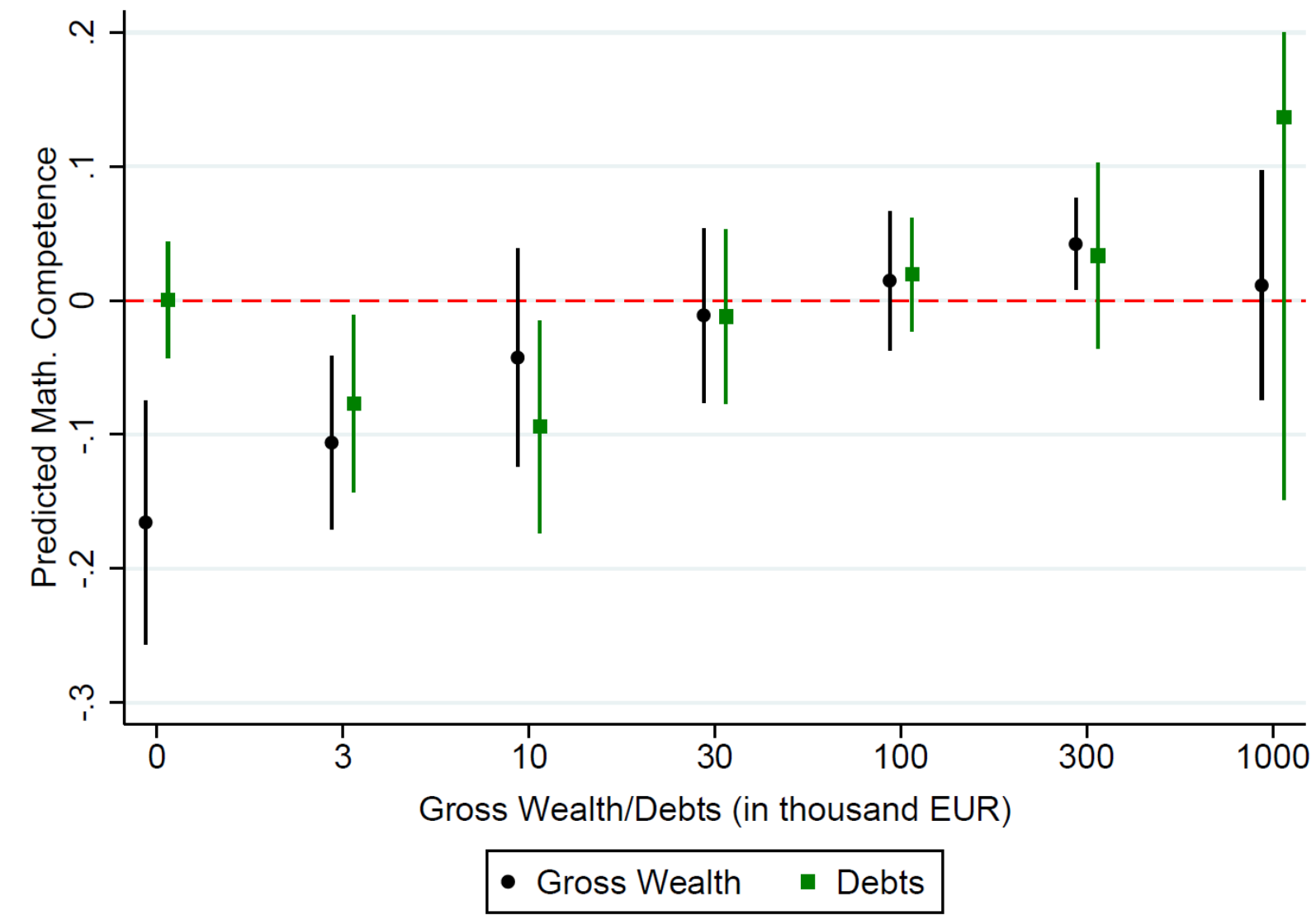

$\mathrm{N}=4,611$. Multiple imputed data $(\mathrm{M}=100)$ of NEPS starting cohort Kindergarten, Sample A. Horizontal lines show 95\%-confidence intervals. 
Figure A4: Predicted probability to attend the highest track by parental net worth and marks

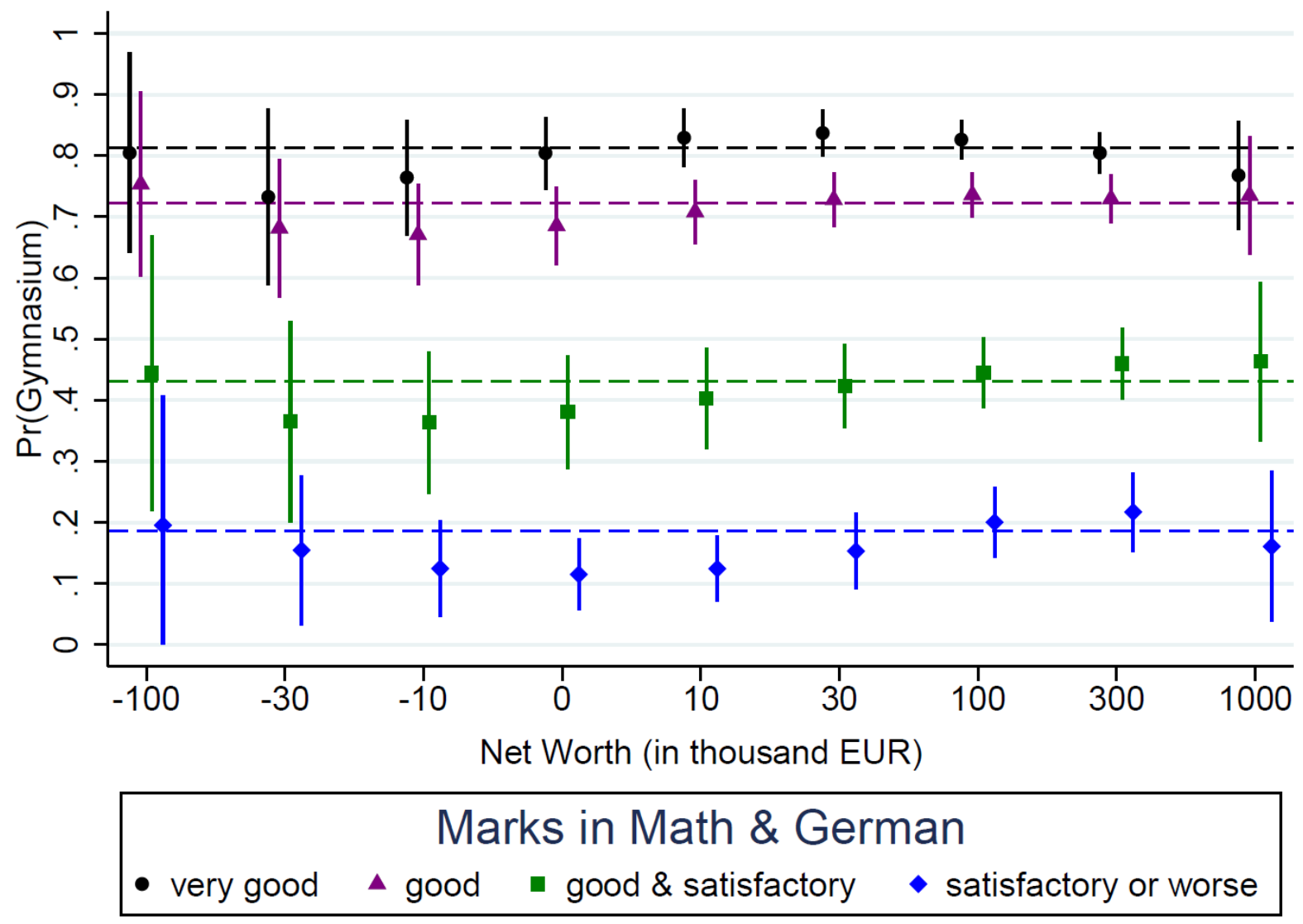

$\mathrm{N}=4,572$. Multiple imputed data $(\mathrm{M}=100)$ of NEPS starting cohort Kindergarten, Sample B. Horizontal lines show 95\%-confidence intervals. 


\section{Online Supplements}

Table S1: Association between parental net worth and parental SES (in 2014)

\begin{tabular}{|c|c|c|c|}
\hline & Net Worth & Income & ISCED \\
\hline Income & 0.360 & & \\
\hline ISCED & 0.267 & 0.476 & \\
\hline EGP & 0.243 & 0.437 & 0.555 \\
\hline
\end{tabular}

$\mathrm{N}=4,611$. Multiple imputed data $(\mathrm{M}=100)$ of NEPS starting cohort Kindergarten, Sample A. Spearman's rank correlations. Average values across all imputations. All values are significant at $1 \%$ level. 
Table S2: Association between parental net worth and parental SES (in 2014)

\begin{tabular}{|c|c|c|c|}
\hline & Net Worth & Income & ISCED \\
\hline Income & 0.372 & & \\
\hline ISCED & 0.271 & 0.480 & \\
\hline EGP & 0.249 & 0.431 & 0.543 \\
\hline
\end{tabular}

$\mathrm{N}=4,572$. Multiple imputed data $(\mathrm{M}=100)$ of NEPS starting cohort Kindergarten, Sample B.

Spearman's rank correlations. Average values across all imputations. All values are significant at $1 \%$ level. 
Table S3: Random-effects regression of math competence (unstandardized coefficients, standard errors in parenthesis)

\begin{tabular}{|c|c|c|}
\hline & $\mathrm{b}$ & SE \\
\hline \multicolumn{3}{|l|}{ Year } \\
\hline 2014 & -0.014 & $(0.029)$ \\
\hline 2016 & -0.040 & $(0.029)$ \\
\hline Net worth (IHS) & $2.59 * 10^{-6}$ & $2.13 * 10^{-6}$ \\
\hline Net worth (IHS) ${ }^{2}$ & $2.23 * 10^{-10} * *$ & $8.65 * 10^{-11}$ \\
\hline Net worth (IHS) ${ }^{3}$ & $-3.69 * 10^{-15}+$ & $1.98 * 10^{-15}$ \\
\hline Net worth (IHS) ${ }^{4}$ & $-6.19 * 10^{-20}+$ & $3.33 * 10^{-20}$ \\
\hline Net worth (IHS) & $7.64 * 10^{-25}$ & $4.77 * 10^{-25}$ \\
\hline \multicolumn{3}{|l|}{ Year*Net worth } \\
\hline $2014 *$ Net worth $($ IHS $)$ & $-3.39 * 10^{-7}$ & $1.94 * 10^{-6}$ \\
\hline $2014 *$ Net worth $(\text { IHS })^{2}$ & $4.38 * 10^{-12}$ & $7.83 * 10^{-11}$ \\
\hline $2014 *$ Net worth $(\text { IHS })^{3}$ & $1.12 * 10^{-15}$ & $1.86 * 10^{-15}$ \\
\hline $2014 *$ Net worth $(\text { IHS })^{4}$ & $2.31 * 10^{-21}$ & $3.03 * 10^{-20}$ \\
\hline $2014 *$ Net worth $(\text { IHS })^{5}$ & $-3.71 * 10^{-25}$ & $4.54 * 10^{-25}$ \\
\hline $2016 *$ Net worth (IHS) & $4.99 * 10^{-7}$ & $1.97 * 10^{-6}$ \\
\hline $2016 *$ Net worth $(\text { IHS })^{2}$ & $-1.87 * 10^{-11}$ & $8.22 * 10^{-11}$ \\
\hline $2016 *$ Net worth $(\text { IHS })^{3}$ & $5.96 * 10^{-16}$ & $1.82 * 10^{-15}$ \\
\hline $2016 *$ Net worth $(\text { IHS })^{4}$ & $1.73 * 10^{-20}$ & $3.18 * 10^{-20}$ \\
\hline $2016 *$ Net worth $(\text { IHS })^{5}$ & $-2.09 * 10^{-25}$ & $4.51 * 10^{-25}$ \\
\hline \multicolumn{3}{|l|}{ Income category (in EUR) } \\
\hline 2. Quintile & -0.027 & $(0.029)$ \\
\hline 3. Quintile & -0.003 & $(0.029)$ \\
\hline 4. Quintile & 0.040 & $(0.032)$ \\
\hline 5. Quintile & 0.046 & $(0.034)$ \\
\hline \multicolumn{3}{|l|}{ Highest ISCED } \\
\hline 3 & 0.057 & $(0.066)$ \\
\hline 4 & $0.200^{*}$ & $(0.078)$ \\
\hline $5 B$ & $0.223^{* *}$ & $(0.076)$ \\
\hline $5 A$ & $0.431^{* * *}$ & $(0.076)$ \\
\hline 6 & $0.541^{* * * *}$ & $(0.096)$ \\
\hline \multicolumn{3}{|l|}{ Highest EGP } \\
\hline II & -0.000 & $(0.026)$ \\
\hline III $a, I V$ & $-0.057+$ & $(0.032)$ \\
\hline$I I I b, V, V I, V I I$ & $-0.092^{*}$ & $(0.037)$ \\
\hline \multicolumn{3}{|l|}{ Generation status } \\
\hline First generation & -0.082 & $(0.086)$ \\
\hline
\end{tabular}


Second generation

$-0.133^{* *}$

Third generation

$-0.152^{*}$

(0.048)

(0.069)

Family status

divorced or widowed

$-0.040$

$(0.045)$

single

$-0.058$

Number of siblings

$-0.054^{* * *}$

(0.012)

East

$-0.060$

$(0.035)$

Unemployed

$-0.007$

$(0.035)$

Parent's age

$-0.008^{* *}$

(0.002)

Mothertongue: German

$0.105+$

Biological parents

$0.101^{*}$

Girl

$-0.188^{* * * *}$

$(0.024)$

Child's age

$-0.004+$

Constant

$17.337^{\text {*** }}$

$(5.058)$

Person-years

13,833

$\mathrm{N}$

4,611

Multiple imputed data $(M=100)$ of NEPS starting cohort Kindergarten; Sample A. Reference categories: Year: 2013; Income: 1. Quintile; ISCED: 2 or less; EGP: I; Generation Status: native; Family Status: Married. Significance levels: $* * *=p<0.001, * *=p<0.01, *=p<0.05,+=$ $\mathrm{p}<0.10$. 
Table S4: Logistic regression of attending the highest secondary school track (log odds; standard errors in parenthesis)

\begin{tabular}{|c|c|c|c|c|}
\hline & $\begin{array}{l}\text { Model } 1 \\
\text { b }\end{array}$ & SE & $\begin{array}{l}\text { Model } 2 \\
\text { b }\end{array}$ & SE \\
\hline $\begin{array}{l}\text { Net worth (IHS) } \\
\text { Net worth (IHS) } \\
\text { Net worth (IHS) } \\
\text { Net worth (IHS) }^{4} \\
\text { Net worth (IHS) }^{5}\end{array}$ & $\begin{array}{l}9.54 * 10^{-6} * \\
5.24 * 10^{-10} * * \\
-1.06 * 10^{-14} * \\
-1.44 * 10^{-19}+ \\
2.13 * 10^{-24}+\end{array}$ & $\begin{array}{l}4.86 * 10^{-6} \\
2.02 * 10^{-10} \\
4.74 * 10^{-15} \\
7.50 * 10^{-20} \\
1.12 * 10^{-24}\end{array}$ & $\begin{array}{l}8.21 * 10^{-6} \\
3.67 * 10^{-10} \\
-9.47 * 10^{-15} \\
-8.42 * 10^{-20} \\
1.67 * 10^{-24}\end{array}$ & $\begin{array}{l}5.87 * 10^{-6} \\
2.46^{*} 10^{-10} \\
5.80 * 10^{-15} \\
8.99 * 10^{-20} \\
1.38 * 10^{-24}\end{array}$ \\
\hline $\begin{array}{l}\text { Income category (in EUH } \\
\text { 2. Quintile } \\
\text { 3. Quintile } \\
\text { 4. Quintile } \\
\text { 5. Quintile }\end{array}$ & $\begin{array}{l}0.071 \\
0.306^{*} \\
0.413^{* *} \\
0.638^{* * *}\end{array}$ & $\begin{array}{l}(0.133) \\
(0.133) \\
(0.131) \\
(0.134)\end{array}$ & $\begin{array}{l}0.018 \\
0.219 \\
0.288+ \\
0.556^{* * *}\end{array}$ & $\begin{array}{l}(0.168) \\
(0.167) \\
(0.161) \\
(0.167)\end{array}$ \\
\hline $\begin{array}{l}\text { Highest ISCED } \\
3 \\
4 \\
5 B \\
5 A \\
6\end{array}$ & $\begin{array}{l}0.655^{*} \\
1.072^{* * *} \\
1.066^{* * *} \\
1.584^{* * *} \\
1.831^{\text {*** }}\end{array}$ & $\begin{array}{l}(0.277) \\
(0.295) \\
(0.287) \\
(0.291) \\
(0.331)\end{array}$ & $\begin{array}{l}0.570+ \\
0.739^{*} \\
0.818^{*} \\
1.081^{* *} \\
1.131^{* *}\end{array}$ & $\begin{array}{l}(0.339) \\
(0.362) \\
(0.350) \\
(0.352) \\
(0.398)\end{array}$ \\
\hline $\begin{array}{l}\text { Highest EGP } \\
\text { II } \\
I I I a, I V \\
I I I b, V, V I, V I I\end{array}$ & $\begin{array}{l}-0.191^{*} \\
-0.190+ \\
-0.513^{* * *}\end{array}$ & $\begin{array}{l}(0.086) \\
(0.112) \\
(0.131)\end{array}$ & $\begin{array}{l}-0.270^{* *} \\
-0.160 \\
-0.395^{*}\end{array}$ & $\begin{array}{l}(0.102) \\
(0.136) \\
(0.155)\end{array}$ \\
\hline $\begin{array}{l}\text { Generation status } \\
\text { First generation } \\
\text { Second generation } \\
\text { Third generation }\end{array}$ & $\begin{array}{l}0.543+ \\
0.227+ \\
-0.171\end{array}$ & $\begin{array}{l}(0.278) \\
(0.132) \\
(0.187)\end{array}$ & $\begin{array}{l}0.708^{*} \\
0.286+ \\
-0.189\end{array}$ & $\begin{array}{l}(0.356) \\
(0.159) \\
(0.228)\end{array}$ \\
\hline $\begin{array}{l}\text { Family status } \\
\text { divorced or widowed } \\
\text { single }\end{array}$ & $\begin{array}{l}0.101 \\
-0.101\end{array}$ & $\begin{array}{l}(0.173) \\
(0.146)\end{array}$ & $\begin{array}{l}0.186 \\
-0.107\end{array}$ & $\begin{array}{l}(0.209) \\
(0.170)\end{array}$ \\
\hline $\begin{array}{l}\text { Number of siblings } \\
\text { East } \\
\text { Unemployed } \\
\text { Parent's age } \\
\text { Mothertongue: German } \\
\text { Biological parents } \\
\text { Girl } \\
\text { Child's age } \\
\text { Math test score }\end{array}$ & $\begin{array}{l}-0.061+ \\
0.035 \\
0.190 \\
-0.020^{* *} \\
-0.475^{\text {** }} \\
0.165 \\
0.175^{\text {** }} \\
0.022^{\text {** }} \\
-\end{array}$ & $\begin{array}{l}(0.034) \\
(0.109) \\
(0.142) \\
(0.007) \\
(0.155) \\
(0.126) \\
(0.066) \\
(0.008)\end{array}$ & $\begin{array}{l}-0.022 \\
-0.288^{*} \\
0.233 \\
-0.017^{*} \\
-0.717^{* * *} \\
0.065 \\
0.078 \\
0.020^{*} \\
0.416^{* * *}\end{array}$ & $\begin{array}{l}(0.041) \\
(0.129) \\
(0.176) \\
(0.008) \\
(0.190) \\
(0.154) \\
(0.084) \\
(0.010) \\
(0.057)\end{array}$ \\
\hline
\end{tabular}




\begin{tabular}{|c|c|c|c|c|}
\hline Math test score ${ }^{\wedge} 2$ & - & & $-0.075^{*}$ & $(0.035)$ \\
\hline Reading test score & - & & $0.333^{* * *}$ & $(0.056)$ \\
\hline Reading test score $^{\wedge} 2$ & - & & $-0.074^{*}$ & $(0.035)$ \\
\hline \multicolumn{5}{|l|}{ Math mark } \\
\hline 2 & - & & $-0.231+$ & $(0.126)$ \\
\hline 3 & - & & $-1.420^{\text {**** }}$ & $(0.165)$ \\
\hline 4 & - & & $-3.006^{* * * *}$ & $(0.712)$ \\
\hline 5 or 6 & - & & -0.685 & $(0.760)$ \\
\hline \multicolumn{5}{|l|}{ German mark } \\
\hline 2 & - & & $-0.280^{*}$ & $(0.130)$ \\
\hline 3 & - & & $-1.120^{* * * *}$ & $(0.159)$ \\
\hline 4 & - & & $-2.347^{* * * *}$ & $(0.464)$ \\
\hline 5 or 6 & - & & $-1.293+$ & $(0.758)$ \\
\hline Constant & $26.248+$ & (14.143) & 23.342 & (17.119) \\
\hline $\mathrm{N}$ & 4572 & & 4572 & \\
\hline
\end{tabular}

Multiple imputed data $(\mathrm{M}=100)$ of NEPS starting cohort Kindergarten; Sample B. Reference categories: Income: 1. Quintile; ISCED: 2 or less; EGP: I; Generation Status: native; Family Status: Married; Math mark: 1; German mark: 1 . Significance levels: $* * *=p<0.001, * *=$ $\mathrm{p}<0.01, *=\mathrm{p}<0.05,+=\mathrm{p}<0.10$. 
Figure S1: Net Worth Distribution

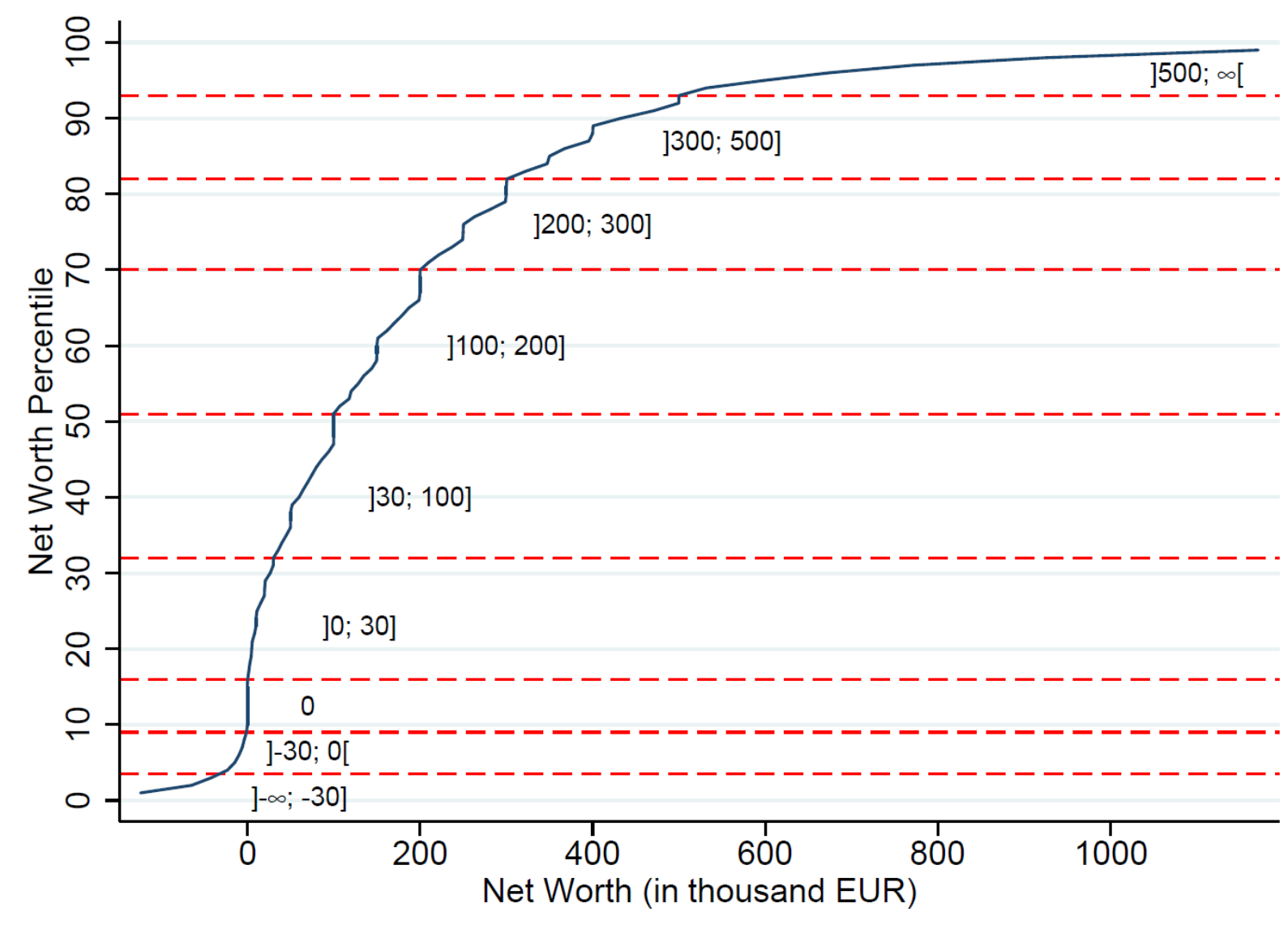

$\mathrm{N}=4,611$. Multiple imputed data $(\mathrm{M}=100)$ of NEPS starting cohort Kindergarten, Sample A. 
Figure S2: Net Worth Distribution

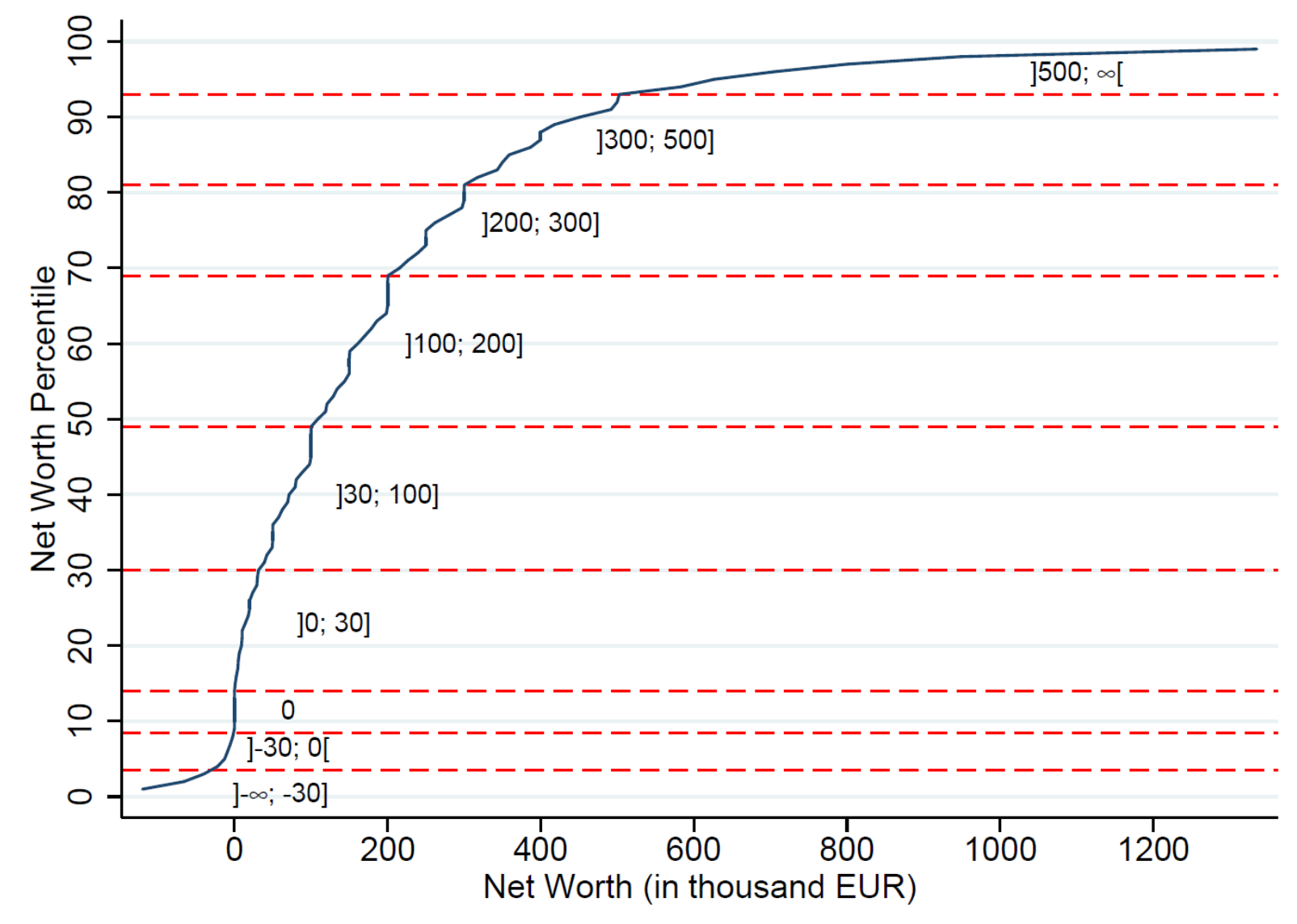

$\mathrm{N}=4,572$. Multiple imputed data $(\mathrm{M}=100)$ of NEPS starting cohort Kindergarten, Sample B. 